\title{
Planlı Dönemde Eğitim Planlaması Çalışmalarının Değerlendirilmesi*
}

\author{
Evaluation of the Education Planning Works in Planned \\ Period
}

\begin{abstract}
Selami YILDIZ**
Öz: Bu çalışmada, Devlet Planlama Teşkilatı (DPT) / Kalkınma Bakanlığı (KB)'nın yaptığı kalkınma planları içindeki eğitim planlaması çalışmaları incelenmiştir. Çalışma kapsamında DPT/KB'de görev alan uzman, uzman yardımcısı ve yöneticilerin görüşleri doğrultusunda; eğitim planlarının nasıl yapıldığının belirlenmesi, planların hazırlık, uygulama, sonuçları izleme aşamalarında yaşanan güçlüklerin saptanması, planlama anlayış̧ında meydana gelen değişikliklerin eğitim planlarına etkisinin ortaya çıkarılması bu araştırmanın problemini oluşturmaktadır. Araştırma kapsamında, DPT/KB'de eğitim planlaması çalışmalarında rol alan kişilerle yarı yapılandırılmış görüşme tekniği kullanılarak yüz yüze görüşmeler yapılmıştır. Araştırmanın kuramsal çerçevesi dikkate alınarak görüşmelerden elde edilen veriler betimsel analiz yöntemiyle incelenmiştir. İnceleme sonucunda; eğitim planlaması çalışmalarında görev alan uzmanların eğitim alanında eğitim alma zorunluluğu bulunmadığı, kalkınma planının bir bütün olarak ele alındığı, diğer sektörler gibi eğitimin de bu planın bir parçası olduğu, mevcut durum ve kaynaklar dikkate alınarak hedeflerin belirlendiği, plan hedefinin belirlenmesinde siyasi otoritenin etkisinin fazla olduğu, planda niceliksel hedeflerin yanında soyut ya da uzun dönemli hedeflerin çoğunlukta olduğu, böyle soyut hedeflerin ne oranda gerçekleştiğini izlemenin güç olduğu, hedeflere ulaşmada karşılaşılan en önemli güçlüğün mali kaynak kısıtı olduğu, DPT’nin KB'ye dönüşmesinin eğitim planlamasına olumsuz yansımalarının olacağı ulaşılan sonuçlardan bazılarıdır.

Anahtar Kelimeler: Eğitim planlaması, sosyal planlama, Devlet Planlama Teşkilatı, Kalkınma Bakanlığı
\end{abstract}

\begin{abstract}
In this study, education planning practices carried out within development plans by the State Planning Organization / Ministry of Development were investigated. The research question of the current study involves; determining how the education plans are developed, identifying the problems encountered during preparation, application and monitoring phases of the education plans, and identifying the effects of the changes in planning approach to the education plans, based on opinions of the specialists, assistant specialists and the managers. For data collection, semi-structured interviews were conducted with professionals who paly a role in educational planning in the State Planning Organization / Ministry of Development. Based on the theoretical framework of the research, descriptive analysis was applied to the collected data. The results showed that: the training in education field was not a professional requirement for education planning experts, the development plan was taken as a whole and that education is a part of the development plan like the other sectors, identification of targets was done considering the current situation and resources, the target of the plans were heavily inluenced by political authorities, the education plans included abstract or long-term goals as well as qualitative targets and that it is challenging to monitor realization of such abstracxt targets, most important challenge for achieving the goals was limited financial resources, and finally, transformation of the State Planning Organization to Ministry of Development would have a negative effects on education planning.
\end{abstract}

Keywords: Education Planning, social planning, State Planning Organization, Ministry of Development

\footnotetext{
*Bu makale, yazarın Prof. Dr. Kasım Karakütük danışmanlığında Ankara Üniversitesi Eğitim Bilimleri Enstitüsü Eğitim Ekonomisi ve Planlaması Doktora Programı'nda tamamladığı "Planlı Dönemde Eğitim Planlamas1 Çalışmalarının Değerlendirilmesi” isimli doktora tezinin bir bölümüdür.

**Dr.,e-posta: syildizkayseri@yahoo.com
} 


\section{Giriş}

Problem

Türkiye' de ülke kaynaklarını verimli kullanarak kalkınmayı gerçekleştirebilmek amacıyla 30 Eylül 1960 tarihinde 91 sayılı yasa ile Başbakanlığa bağlı Devlet Planlama Teşkilatı (DPT) kurulmuştur. Bu yasa ile DPT'nin görevi "ekonomik, sosyal ve kültürel politikaların ve hedeflerin belirlenmesinde, ekonomik politikayı ilgilendiren etkinliklerin eşgüdümünde Hükümete yardımcı olmak ve danışmanlık yapmak" şeklinde belirlenmiştir. 1960 yılında kurulan DPT, 2011 yılında çıkarılan "641 sayılı Kalkınma Bakanlığının Teşkilat ve Görevleri Hakkında Kanun Hükmünde Kararname" ile Kalkınma Bakanlığı’na (KB) dönüştürülmüştür. DPT tarafından 1963-2018 yıllarını kapsayan 10 Kalkınma Planı hazırlanmıştır.

Kalkınma kavramı Âdem (1987) tarafından bireylerin gönenç (refah) düzeyini yükseltmek amacıyla siyasal iktidarın belli ekonomi ve toplumsal politikalar izleyerek toplumun yapısını değiştirme girişimi olarak tanımlanmıştır. Kalkınma, bir ülkenin yurttaşlarının daha iyi bir yaşam sürdürmelerini sağlar (Karakütük, 2012, s. 20). Planlı kalkınmanın genel amacını; Karayalçın (1974), Türk toplumunu "İnsanlık onuruna yaraşır" bir yaşayış düzeyine ulaştırmak şeklinde, Börtücene (1973), sosyal hedefleri güvence altına almak, yaşama düzeyini yükseltmek, çalışma gibi sosyal ve ekonomik güvenceleri topluma yaygınlaştırmak, yaşam düzeyinde gelişmeler ve sosyal ve ekonomik alanlarda bireylere her türlü katılma ve fursat eşitliği olanaklarını hazırlamak şeklinde açıklamıştır.

Kalkınma kavramı, ekonomik ve toplumsal yönden gelişmiş olmayı belirtmektedir. Ekonomik kalkınma için iktisadî konular ele alınırken, toplumsal kalkınma için nüfus politikası, insangücü, istihdam, iş ve işçi konuları, sosyal güvenlik, eğitim, sağlı, sosyal hizmetler, araştırma, kültür, konut, bölge planlaması ve diğer kamu hizmetleri konuları ele alınmaktadır. Ekonomik kalkınma başlamadan sosyal gelişme düzeyi yükselemeyeceği gibi sosyal çevre koşullarının dinamizm kazanmadığı ve modernleşmeye katkı sağlamadığı toplumlarda da iktisadî kalkınma gerçekleştirilememektedir (Gonca, 1983, s. 2). Bu nedenle ekonomik ve sosyal kalkınma planları birbirinden ayrı bağımsız planlar olmamalı, birbirini tamamlar nitelikte olmalidir.

DPT’nin kurulduğu yıllarda ekonomik planlama İktisadî Planlama Dairesi, sosyal planlama ise Sosyal Planlama Dairesi tarafindan yapılmaktayd1. Ancak birbirini tamamlamas1 gereken sosyal ve iktisadî planlarda ağırlığın iktisadi plan tarafinda olduğu sosyal plan kısmının geri planda kaldığı, İktisadî Planlama Dairesi'nin, Sosyal Planlama Dairesi'ni geri planda bıraktığı Kansu (2004) tarafindan belirtilmektedir. İktisadî alanda yapılan planların sosyal planlara göre daha öncelikli olarak görülmesi sosyal alanlara aktarılan kaynakları da etkilemiştir. $\mathrm{Bu}$ nedenle eğitim, kültür, sağlik gibi sosyal alanlara yönlendirilen kaynaklar (zaman, para, emek) ve uygulamalar bu durumdan olumsuz yönde etkilenmiştir.

Sosyal planlama; sosyal yapıdaki değerleri, kabulleri, davranışları ve yaşama tarzını, gelişmeyi ve bütünleşmeyi esas alan bir yönlendirmedir (Tural, 1986, s. 14). Sosyal planlama da ekonomik planlama gibi, önce sosyal gelişme yönünden nerede olduğumuzla işe başlamakta, daha sonra nereye gideceğimizi ve nasıl gideceğimizi saptayarak, ereklerle kaynaklar arasında bir öncelik sıralaması içinde dengeyi kurmaktadır (Güven, 1995, s. VI).

"Sosyal" kavramı hukuk, insan hakları, kültür, eğitim, sağlık, istihdam vb. konuları içine alan oldukça geniş kapsamlı bir kavramdır. Kalkınma planları içinde yer alan sosyal planlama eğitim, kültür, sağlık gibi alanları kapsamaktadır. Sosyal alan içinde değerlendirilen eğitim, 1960'l1 yıllardan itibaren ulusal gelişmenin bir aracı olarak görülmüş ve eğitime ilgi artmıştır (Hesapçıŏlu, 1984, s. 14).

$\mathrm{Bu}$ araştırmada, DPT/KB tarafından hazırlanan kalkınma planlarının bir parçasını oluşturan sosyal planlama içindeki eğitim planlaması çalışmalarına odaklanılmıştır. Eğitim, sosyal alanın en önemli dinamiklerinden birisidir. Eğitim planlaması Âdem (2008) tarafından "siyasal ve ekonomik gerçekleri, eğitim dizgesinin büyüme gizilgücünü, dizgenin hizmetinde olduğu ülkenin ve öğrencilerin gereksinimlerini dikkate alarak buna ilişkin politikayı, öncelikleri, dizgenin maliyetini kestirmek amaciyla yapılan kestirme girişimleridir" şeklinde tanımlanmaktadır. 
Toplumsal düzenlemelerin biçimlendirilmesinde ya da en geniş anlamıla toplumsal yapının belirlenmesinde eğitim ve öğretim her zaman araç olmuştur (Ergun, 2005, s. 24). Dolayısıyla eğitim, bireyi şekillendirir, istenen şekli alan bireyler de toplumu biçimlendirir. $\mathrm{Bu}$ nedenle, toplumların biçimlendirilmesinde eğitime her zaman büyük önem verilmektedir. Eğitim, bireyi toplumsal açıdan şekillendirirken, ekonomik açıdan da bireye üretme gücü kazandırmaktadır. Bu üretme gücü nedeniyle sanayi üretiminde rol alabilecek nitelikte ve yeterli sayıda insangücü ile gerçekleştirilebileceği düşüncesi, kalkınma planları içinde eğitim planlarının da yer almasını gerektirmiştir (Ünal ve Özsoy, 2010, s. 255).

Kalkınma planlarında ekonomik ve sosyal alanlar için belirlenen hedefler Türkiye'deki tüm kamu kurum ve kuruluşlarını etkilediği gibi kalkınma planlarında yer alan eğitim planları da başta Milli Eğitim Bakanlığı ve Yükseköğretim Kurulu olmak üzere diğer kamu kuruluşlarının planlarını doğrudan ya da dolaylı olarak etkilemektedir. Dolayısıyla DPT/KB tarafından yapılan planlama çalışmalarında, belirlenen hedeflerin; amaca yönelik, anlaşılabilir, gerçekçi, ölçülebilir, ulaşılabilir ve uygulanabilir olması plan hiyerarşisi gereği tüm kuruluşların çalışmalarını etkilemesi açısından büyük önem taşımaktadır. Bu nedenle eğitim planlamasında görev alan DPT/KB ve diğer kurumlarda çalışan personelin niteliği, eğitim altyapısı, işe uygunluğu, kurumların kendi içinde ve birbirleriyle eşgüdümü, işbirliği, planların uygulanmasına yönelik ayrılan maddi kaynak, zaman, planın sonuçlarının izlenmesi gibi pek çok etken planlamanın amacına ve hedefine ulaşmasını etkilemektedir.

Sezen (1999) planlamanın; "Hazırlık", "Uygulama", "İzleme, Denetleme ve Değerlendirme" olmak üzere üç basamaktan oluştuğunu belirtmektedir. Planın; hedeflerinin açık ve anlaşı1ır olması, koşullara kısa zamanda uyum sağlayabilecek şekilde esnek olması, planlama eylemini oluşturan tüm parçaların birbiriyle uyumlu olması planın başarısı açısından önem taşımaktadır.

Köklü bir planlama kültürüne sahip DPT’nin eğitim planlaması çalışmalarına ilişkin bilgi ve deneyimlerinin bu araştırma kapsamında ele alınmasının eğitim planlaması alanyazınına olumlu katk1 sağlayacağı, onu zenginleştireceği düşünülmektedir. Bu araştırma kapsamında, DPT/KB tarafından yapılan eğitim planlaması çalışmalarında görev alan uzman, uzman yardımcısı ve yöneticilerin görüşlerine başvurulmuştur. Bu görüşlere dayalı olarak;

1. Kalkınma planlarında yer alan eğitim planlaması çalışmalarının kimler tarafindan yapıldığı, planların hazırlık, uygulama ve sonuçları izleme aşamalarına yönelik süreçte neler yaşandığ1, bu süreçte yaşanan güçlüklerin neler olduğunun belirlenmesi,

2. Planlama anlayışına ilişkin dünyada ve ülkemizde yaşanan gelişmelerin DPT/KB tarafindan yapılan eğitim planlarını nasıl etkilediğinin ortaya çıkarılması bu araştırmanın problemini oluşturmaktadır.

\section{Amaç}

$\mathrm{Bu}$ araştırmanın genel amacı, DPT/KB' de eğitim planlaması çalışmalarında görev almış/alan uzmanların, uzman yardımcılarının ve yöneticilerin görüşlerine göre Türkiye'deki eğitim planlaması çalışmalarını değerlendirmektir. Bu genel amaç doğrultusunda aşağıdaki sorulara yanıt aranmıştır:

1. Eğitim planlarında hangi personel görev almıştır? Bu personel hangi eğitimleri almıştır?

2. $\quad$ Eğitim planları yapılırken nasıl bir süreç izlenmiştir?

3. Eğitim planlaması yapılırken bir model (Toplumsal İstem, İnsangücü Gereksinimi, Maliyet/Yarar gibi) temel alınmış mıdır?

4. Eğitim planlaması çalışmalarının öncelikleri neler olmuştur?

5. Eğitim planlarının hedefleri nasıl belirlenmiştir?

6. Plan hedeflerine ulaşılıp ulaşılmadığı nasıl izlenmiştir?

7. Eğitim planlarının hazırlamasında yaşanan güçlükler neler olmuştur?

\section{Önem}

Ülkemizde DPT/KB'nin hazırladığı kalkınma planlarına yönelik birçok araştırma yapılmıştır. $\mathrm{Bu}$ araştırmalarda kalkınma planları içindeki eğitim planlarının kimler tarafından ve nasıl 
yapıldığı, eğitim planlarını hazırlama, uygulama ve sonuçları izleme aşamalarına ilişkin süreç ve bu süreçte yaşanan güçlüklerin belirlemesine yönelik plan çalışmalarında görev alan uzmanların görüşlerinin yer aldığı bir araştırmaya rastlanılmamıştır. Araştırma bu açıdan ilk olması nedeniyle önem taşımaktadır.

DPT/KB'nin belirlediği eğitim hedefleri, eğitim alanında etkinlik gösteren ve planlama yapan bütün kurumların çalışmalarını doğrudan ya da dolaylı olarak etkilemektedir. $\mathrm{Bu}$ araştırma ile DPT/KB tarafindan yapılan eğitim planlamasının hazırlık, uygulama ve sonuçları izleme aşamaları ile planın oluşturulmasında yaşanan güçlüklerin betimlenmesinin eğitim planlaması çalışmalarına 1şık tutacağı, planlamaya ilginin azaldığı şu günlerde planlamanın önemine katk1 sağlanacağı, köklü bir planlama kültürüne sahip DPT'nin eğitim planlamas1 çalışmalarına ilişsin bilgi ve deneyimlerinin eğitim planlaması alanyazınını zenginleştireceği umulmaktadir.

\section{Sinırlılıklar}

Araştırma, belgesel tarama yöntemiyle ulaşılan bilgiler ile DPT/KB'de eğitim planlamas1 çalışmalarında görev almış personelin konuyla ilgili bildirdikleri görüşlerinin çözümlenmesinden elde edilen veriler ile sınırlıdır.

\section{Yöntem}

\section{Araştırmanın Modeli}

$\mathrm{Bu}$ araştırmada, nitel araştırma desenlerinden durum çalışması deseni kullanılmıştır. Araştırma kapsamında DPT/KB tarafından yapılan eğitim planlarına, plan çalışmalarında görev alan personelin görüşleri doğrultusunda bir 1şı tutulmuş, konu, kapsamı çerçevesinde derinlemesine incelenmiştir. Kalkınma planlarında yer alan eğitim planlarına ilişkin geçmişte DPT/KB'de çalışmış ya da halen çalışmakta olan planlama uzmanı, uzman yardımcısı ve yöneticiler ile yarı yapılandırılmış görüşme tekniği ile görüşmeler yapılmıştır.

\section{Araștırma Grubu}

Araştırma'da DPT/KB'nin yaptığı eğitim planlaması çalışmalarında görev alan planlama uzmanı, uzman yardımcısı ve yöneticilerin görüşlerine başvurulmuştur. Görüşme yapılması planlanan 29 kişiden görüşmeyi kabul eden 10 kişi ile araştırmanın genel amacı ve alt amaçları doğrultusunda hazırlanan yarı yapılandırılmış sorular kullanılarak 2014 yılının Ekim ayında yüz yüze görüşmeler yapılmıştır. Araştırmanın çalışma grubunu DPT/KB' de eğitim planlaması çalışmalarında uzman yardımcısı, uzman, daire başkanı, şube müdürü olarak görev alan 10 kişi oluşturmaktadır.

\section{Veri Toplama Araç ve Teknikleri}

Araştırma kapsamında kullanılan veri kaynakları üç grupta toplanabilir. Birinci grupta kuramsal çerçevenin oluşturulmasına yönelik kitap, tez, makale vb. belgeler, ikinci grupta kalkınma planları, yıllık programlar, orta vadeli programlar, özel ihtisas komisyonu raporları vb. belgeler, üçüncü grupta da plan çalışmalarında görev alan personel ile yapılan görüşmeler sonucunda elde edilen bilgiler siralanabilir.

$\mathrm{Bu}$ araştırmanın temel veri kaynağını görüşmelerden elde edilen bilgiler oluşturmaktadır. DPT/KB'nin yaptı̆̆ eğitim planlaması çalışmalarına ilişkin görüş, deneyim, duygu, tutum ve düşünceleri bu araştırma kapsamında ele alınmıştır. Görüşme yapılan kişilerin istekleri doğrultusunda kimlik bilgileri belirtilmemiştir. Görüşülen kişilerin kimlik bilgileri yerine 1'den 10'a kadar numara verilerek "Görüşme Yapılan Kişi" ifadesinin baş harfleri kullanılarak GYK-1, GYK2,.......GYK-10 şeklinde kodlanmıştır. Görüşme yapılan kişiler ile ilgili bilgiler Tablo 1'de verilmiştir. 
Tablo 1

Görüşme Yapılan Kişilere İlişkin Bilgiler

\begin{tabular}{|c|c|c|c|c|}
\hline Kod & Cinsiyet & $\begin{array}{l}\text { DPT/KB' deki } \\
\text { Görevi* }\end{array}$ & Lisans Eğitimi & $\begin{array}{l}\text { DPT/KB' de Halen } \\
\text { Çalışma Durumu }\end{array}$ \\
\hline GYK-1 & Erkek & Uzman & Kamu Yönetimi & Çalışmıyor \\
\hline GYK-2 & Kadın & Müsteşar Danışmanı & İktisat & Çalışmiyor \\
\hline GYK-3 & Erkek & Müsteşar Danışmanı & Bankacıllk ve Finansman & Çalışıyor \\
\hline GYK-4 & Erkek & Daire Başkanı & Kamu Yönetimi & Çalışıyor \\
\hline GYK-5 & Erkek & Uzman & Maliye & Çalışmıyor. \\
\hline GYK-6 & Erkek & Uzman & $\begin{array}{l}\text { Eğitim Yönetimi Planlamas1 } \\
\text { ve Ekonomisi }\end{array}$ & Çalışmıyor \\
\hline GYK-7 & Erkek & Uzman & Ziraat Mühendisi & Çalışmıyor \\
\hline GYK-8 & Erkek & Uzman & $\begin{array}{l}\text { Eğitim Yönetimi Planlamas1 } \\
\text { ve Ekonomisi }\end{array}$ & Çalışmıyor \\
\hline GYK-9 & Erkek & Uzman & Fizik Mühendisi & Çalışıyor \\
\hline $\begin{array}{l}\text { GYK- } \\
10\end{array}$ & Kadın & Uzman & Kamu Yönetimi & Çalışıyor \\
\hline
\end{tabular}

* DPT/KB'de en son bulunulan görev yazılmıştır.

Görüş̧mede kullanılan sorular nitel veri toplama yöntemine uygun olarak araştırmanın genel amacı ve alt amaçları doğrultusunda, eğitim yönetimi, eğitim planlaması, eğitim istatistiği, bilimsel araştırma yöntemleri konusunda uzman olan 13 alan uzmanından destek alınarak hazırlanmıştır. Alan uzmanlarının katkılarıyla hazırlanan araştırma soruları aşağıda sunulmuştur:

1. Devlet Planlama Teşkilatı/Kalkınma Bakanlığı'nda hangi görevlerde bulundunuz, halen çalışıorsanız hangi görevde bulunuyorsunuz?

2. Devlet Planlama Teşkilatı/Kalkınma Bakanlığı'nda eğitim planlaması çalışmalarında ne kadar süre görev aldınız/alıyorsunuz?

3. Eğitim planlaması yaparken nasıl bir süreç izlemektesiniz? (SONDA; Eğitim planlaması süreci ne zaman, nasıl başlıyor. Eğitim planlamasının başlangıcından bitimine kadar geçen süreçte yer alan aşamalar ve yürütülen çalışmalar hakkında bilgi verir misiniz?

4. Eğitim planlaması çalışmaları sürdürülürken belirli bir eğitim planlaması yaklaşımı (Toplumsal İstem, İnsangücü Gereksinimleri, Maliyet/Yarar gibi) temel alındı mı? Alındı ise hangi model temel alındı?

5. Size göre eğitim planlaması sürecinde öncelikler neler olmuştur? Bu öncelikler nasıl belirlendi? Öncelikler belirlenirken karar alma sürecinde kimler yer almıştır?

6. Eğitim planlaması sürecinde hedefler nasıl belirlenmiştir/belirlenmektedir?

7. Plan hedeflerine ulaşılıp ulaşılmadığı nasıl izlenmiştir/izlenmektedir? Plan hedeflerine ulaşılamadı ise bunun nedenleri neler olabilir?

8. Eğitim planlaması sürecinde belirlenen hedeflere yönelik işlemler nasıl izlenmektedir? Hedeflere yönelik işlemlerin izlenmesinde yaşanan güçclükler nelerdir?

9. Eğitim planlaması sürecinde görev alan personel, eğitim planlaması konusunda eğitim almış mıdır? Almışsa hangi eğitimleri almıştır?

10. DPT'de görev aldığınız dönemdeki eğitim planlaması sürecini dikkate alarak bugün $\mathrm{DPT} / \mathrm{KB}$ ' deki eğitim planlaması sürecini değerlendirebilir misiniz?

\section{Verilerin Analizi ve Değerlendirilmesi}

Görüşme yoluyla deneyimler, tutumlar, düşünceler, niyetler, yorumlar, zihinsel algilar ve tepkiler gibi gözlemlenemeyen konular ya da durumlar anlamaya çalış1ır (Yıldırım ve Şimşek, 2011 , s. 120). Bu araştırmanın temel veri kaynağını görüşmelerden elde edilen bilgiler oluşturmaktadır. DPT/KB'nin yaptı̆̆ e ğitim planlaması çalışmalarında görev alan personelin eğitim planlaması çalışmalarına ilişkin görüş, deneyim, duygu, tutum ve düşünceleri bu araştırma kapsamında ele alınmıştır. 
$\mathrm{Bu}$ araştırma kapsamında; araştırmanın genel amacı ve alt amaçları doğrultusunda eğitim planını hazırlama süreci, önceliklerin ve hedeflerin belirlenmesi, planı hazırlayanların eğitim planlaması konusundaki altyapısı, planın uygulanması ve sonuçlarının izlenmesi, yaşanılan güçlüklerin ortaya çıkarılmasına yönelik kuramsal bilgiler ışığında ve görüşme sonuçlarından elde edilen bulgular dikkate alınarak betimsel analiz yapılmıştır.

\section{Bulgular}

Görüşülenlerin Devlet Planlama Teşkilatı/Kalkınma Bakanlı̆̆ı'nda Bulundukları Görevlere İlişkin Bulgular

Görüşme yapılan kişilerin DPT/KB'de görev yaptıkları dönemlerde uzman yardımcısı, uzman, daire başkanı, şube müdürü, genel müdür, müsteşar danışmanı, müsteşar yardımcısı görevlerinde bulundukları belirlenmiştir.

\section{Görüşülenlerin Devlet Planlama Teşkilatı/Kalkınma Bakanlı̆̆ı'nda Ĕ̈itim Planlaması Çalışmalarında Görev Aldıkları Sürelere İlişkin Bulgular}

Görüşme yapılan kişilerin eğitim planlaması çalışmalarında görev aldıkları süreler Tablo 2'de gösterilmiştir. Görüşme yapılan kişilerin eğitim planlaması çalışmalarında görev aldıkları süre en az 4,5 en çok 30 yıl olmak üzere ortalama 14 yıl olarak belirlenmiştir.

Tablo 2

Görüşme Yapılan Kişilerin Eğitim Planlaması Çalışmalarında Görev Aldıkları Süre

\begin{tabular}{lcccccccccc}
\hline \multirow{2}{*}{ Personel } & GYK & GYK & GYK & GYK & GYK & GYK & GYK & GYK & GYK & GYK \\
& 1 & 2 & 3 & 4 & 5 & 6 & -7 & -8 & -9 & -10 \\
\hline Süre (Y11) & 5 & 25 & 30 & 8 & 20 & 10 & 12 & 23 & 4,5 & 4,5 \\
\hline
\end{tabular}

Ĕ̆itim Planlaması Sürecinde Görev Alan Personelin, Ĕ̈itim Planlaması Konusunda Ĕ̈itim Alıp Almadığına İlişkin Bulgular

Eğitim planlaması sürecinde görev alan personelin, eğitim planlaması konusunda eğitim alıp almadığına ilişkin görüşme yapılan kişilerden aşağıdaki veriler elde edilmiştir;

“...Tarihi usta çırak ilişkisi içerisinde yetişirlerdi...DPT yurt dışına master için lüzum görülen dallarda, birçok uzmanı, uzman yardımcısını göndermiştir.” (GYK-1)

"Hizmet içi eğitimlerle DPT tanıtıllyor...Uzman yardımcıları eğitimlerini, uzmanların yanında alıyor. Göreve başladıktan ü̧̈ sene sonra da tez hazırlıyorlar...Yurt dışı mastır imkânlarl var." (GYK-2)

"Uzman yardımcıları hizmet içi eğitim alıyorlar...Tez süreci zaten başlı başına bir eğitim..." (GYK-3)

"İsler burada sektörde ögreniliyor. Burası okul gibi." (GYK-4)

"Sistematik bir eğitim yoktur." (GYK-6)

"DPT'de usta çırak ilişsisiyle çok güzel yetiştiriyoruz. Yüksek lisans eğitimi için yurt dışına gidiyorsunuz. Tez hazırlama süreci takip ediliyor." (GYK-7)

"DPT'nin yaptığı işleri anlatmak amacıyla oryantasyon eğitimi verilir...uzman yardımcısı, mastır için yurt dışına gönderilir...dil öğretimi için yurt dışına gönderiyor." (GYK-8)

"Eğitim planlaması konusunda bir ĕgitim aldı̆̆ını düşünmüyorum. Sadece planlama atmosferini teneffüs ederek planlama nosyonunu almıştır arkadaşlarımız...uzman yardımcıları üç sene sonunda bir tez hazırlayıp uzmanlık imtihanına girmek zorundadirlar." (GYK-9)

“...seminer, sempozyum, eğitim programlarına katıllyoruz...Uzman olduktan sonra yurt dışında mastır imkânı var.” (GYK-10) 
Görüşme yapılan kişilerin büyük çoğunluğunun görüşüne göre;

DPT'de göreve başlayan ve eğitim planlaması çalışmalarında çalışma yapacak uzman yardımcıları, diğer sektörlerde çalışacak uzman yardımcıları gibi DPT/KB, Türkiye'deki önemli kurum ve kuruluşlar ile önemli projelerin tanıtıldığı ortalama bir-iki ay süreyle hizmet içi eğitime tabi tutulmaktadırlar. Bu hizmet içi eğitimler mesleğin başlangıcında oryantasyon eğitimi şeklinde verilirken, meslek yaşamı boyunca da DPT/KB içindeki yeni bir sistemin tanıtımı ya da bir konuda bilgilendirme şeklindeki kurs ve eğitimlerden oluşmaktadır.

Eğitim planlaması konusunda çalışacaklara bu konuda kurumsal olarak sistematik bir eğitim verilmemektedir. Ancak bütçe imkânları dikkate alınarak uzmanların isteği doğrultusunda yurt dışında kurs ve eğitime gönderilebilmektedirler. Uzmanların esas yetişmelerinin her bir uzman yardımcısının deneyimli bir uzmanla beraber çalışarak yani usta çırak ilişkisiyle sağlandığı görülmektedir. $\mathrm{Bu}$ yöntemin çok verimli bir yöntem olduğu görüşülen kişiler tarafindan özellikle vurgulanmaktadır.

Uzman yardımcılarının bütçe olanakları doğrultusunda yurt dışına yüksek lisans, yurt içinde de yüksek lisans ve doktora eğitimine gönderilmesi uzman yardımcısının kendini mesleki ve bireysel yönden geliştirmesine katkı sağlamaktadır. Uzman yardımcıları göreve başladıktan üç yıl sonra bir uzmanlık tezi hazırlamaktadırlar. Bu tez süreci DPT/KB tarafından çok ciddi bir şekilde ele alınmakta, kurumsal olarak tez hazırlanmasına büyük önem verilmektedir.

Uzmanların yurt içinde ve yurt dışında seminer, konferans, kongre gibi bilimsel etkinliklere katılımı özellikle özendirilmektedir. Bu tür etkinliklere personelin katılımı olumlu karşılanmakta, personelin kendini geliştirmesini sağlayan bir etken olarak görülmektedir.

DPT/KB'nin bütçe olanakları dikkate alınarak yabancı dil düzeyi yeterli olmayanlar da yurt dışına yabancı dil eğitimine gönderilebilmektedir.

\section{Ĕgitim Planlaması Yaparken İzlenen Sürece İlişkin Bulgular}

Eğitim planlaması sürecinin ne zaman ve nasıl başladığına ilişkin;

"DPT, planın yürürlüğe girmesinden bir buçuk sene evvel çalışmaları başlatır." (GYK-2)

“...Genellikle bir buçuk yıl öncesinden hazırlıkların başlamasına yönelik bir karar alınıyor...Başbakanlık genelgesinin yayınlanmasının ardından çalışmalara başlıyoruz." (GYK3)

Planın yürürlüğe girmesinden bir buçuk sene öncesinden yayınlanan Başbakanlık genelgesinin ardından plan hazırlıklarına başlandığı GYK-2 ve GYK-3 tarafindan ifade edilmiştir.

Kalkınma planı ile eğitim planı arasındaki ilişki kapsamında görüşülen kişilerin görüşlerine baktığımızda;

"Kalkınma planını hazırlama süreciyle, eğitim planını hazırlama süreci aynı. (GYK-3) Bütün sistem, bir plan modeline, bir kurguya göre işliyor...Burada büyük resmi görmek, bunların arasindaki ilişkiyi bilmek lazım." (GYK-7)

"Planlama çalışmalarına başlamadan önce ilgili bakan veya müsteşarın başkanlığında daire başkanı ve üstü seviyede yapılan toplantılarda bir takım büyüklüklere karar veriliyor..." (GYK-7)

"Ĕ̆itim planlaması tek başına bă̆ımsız bir plan değil...Kalkınma politikasıyla ilgili, kalkınma politikası da ülkenin genel politikastyla ilgili..." (GYK-2)

"Plan süreci bütün sektörler için aynıdır..." (GYK-10)

GYK-2, GYK-3, GYK-7, GYK-10 tarafindan ifade edilen görüşlere göre;

Kalkınma planı içinde eğitim planlaması ayrı bir plan olarak değerlendirilmemekte, kalkınma planının bir parçasını oluşturmaktadır. Eğitim planı hazırlama süreciyle kalkınma planı hazırlama süreci arasında bir fark bulunmamaktadır. 
$\mathrm{Bu}$ çalışmalar yapılırken plan hazırlamayla ilgili varolan iş akışı izlenmektedir. Kalkınma planı içinde yer alan eğitim planı, büyük bir planın ve kurgunun bir parçasını oluşturmaktadır. Planı oluşturan parçaların birbirleriyle ilişkileri ve bağlantıları bulunmaktadır.

Kalkınma planlarında yer alan hedefler ve politikalar daire başkanı ve daha üst düzeydeki yöneticiler tarafından belirlenmektedir. bakıldığında;

Eğitim planlamasının hangi ölçekte yapıldığına ilişkin görüşülen kişilerin görüşlerine

"Biz eğitim hedeflerine makro ölçekte baklyorduk. Eğitim planlarındaki il, ilçe düzeyindeki çalı̧̧malar Milli Eğitim Bakanlığı’nın görevi...” (GYK-8)

"Eğitim planları insangücü planlarının içinde yer alıyor. Ayrı bir eğitim planlaması modeli bana göre makro ölçekte ele alınmadı. Ancak yüksekögretim için ayrıca planlar yapıldl..." (GYK-8)

"Bizim eğitim planlamasından kastımız eğitim müfredatı olmuyor. Biz genel politika tespiti yaplyoruz..." (GYK-10)

"Plan hedefleriyle uygun bir şekilde bir kaynak ve insan planlaması yapılır...DPT'nin asıl işi kaynak tahsisidir..." (GYK-1)

Eğitim planlamasının hangi ölçekte yapıldığına ilişkin GYK-1, GYK-8 ve GYK-10 tarafindan ifade edilen görüşlere göre;

DPT/KB kalkınma planları içinde ele alınmakta, eğitim planlamasına makro ölçekte bakmaktadır. İl ve ilçe düzeyindeki eğitim planlaması Milli Eğitim Bakanlığı tarafından yapılmaktadır. Eğitim planları insangücü planları içinde yer almakta, makro ölçekte ayrı bir eğitim planlaması yapılmamaktadır. Eğitim planlaması yapılırken hedefler ve mevcut durum göz önünde bulundurularak genel politika belirlenmekte, eğitim programları ve içeriği üzerinde durulmamaktadır. Eğitim planlamasında plan hedeflerine uygun olarak kaynak ve insan planlamas1 yapılmaktadır.

Eğitim planlaması çalışmalarında kullanılan verilerin nerelerden sağlandığına ilişkin görüşülen kiş̧ilerin görüşlerine bakıldığında;

"Plan çalışmaları kapsamında istediğimiz veriler İstatistik Enstitüsü tarafindan toplanıyor...Türkiye'nin istatistikleri, dünyanın en güvenilir istatistiklerinden biridir." $(G Y K-2)$

Verilerin Türkiye İstatistik Kurumu (TÜİK) (eski adı Devlet İstatistik Enstitüsü) tarafindan sağlandığı ve bu verilerin çok güvenilir olduğu GYK-2 tarafindan ifade edilmiştir.

Eğitim planını hazırlama sürecine ilişkin görüşülen kişilerin görüşlerine baktığımızda;

Eğitim planlamasında üç önemli adım var. Birincisi, mevcut insangücü planlamast. Insangücü planlamasina yönelik İstatistik Enstitüsü vasitaslyla çok kapsamlı araştırmalar yapıyoruz. Bunlar hanehalkı işgücü araştırmalarl, hanehalkı gelir araştırmaları ve sanayi sayımları oluyor... O sektörlerde ve alt sektörlerde yani iş kollarında ne kadar insangücü ihtiyacı olduğunu belirliyoruz. İkinci adımda bu araştırmalarla ileride yatırım yapılacak alanları tespit ederek gelecekte ne kadar işgücüne ihtiyacımız olacağını belirliyoruz. Üçüncü adımda, planlar her zaman piyasada olandan daha ilerisinde hedefler verirler ki o dönem kendisini zorlasin ve daha fazla yatırım yapılsin daha fazla kalkınma meydana gelebilsin diye. Bu yaratılacak ilave kapasitenin gerektirdiği insangücünü de plana dâhil ediyoruz... Eğitim planlama sürecinde PERT şeması yapıyoruz. Onun üzerinden hangi gün, kim, nereye çalı̧̧malarını hazırlayıp verecek belirliyoruz. Bir de operation research (yöneylem araştırması) yöntemini kullanıyoruz. Bütün bunlarda, kimin, kime, ne zaman, ne vereceği belli olduğu için bunlar bir çeşit görev tanımı haline geliyor...makro modelde girdi çıktı tablolarıyla yani hangi sektörün malı çıkıp hangi 
sektöre girdi olacak, hangi mallar nihai mal olarak çıkacak. Bu makro modeli yapıp işlettikten sonra buradan seçenekler çıkarıyoruz... Bunları Yüksek Planlama Kurulu'na götürüyoruz...Eğitim planlamasına başllyoruz. Bu süreçte yaş grupları, kız-erkek dağılımları, bunların ileride hangi yıl kaç yaşına gelecekleri gibi nüfus istatistiklerine ihtiyacımız oluyor. Milli Eğitim Bakanlı̆̆g'nda hangi alanda kaç ögrenci var, bunlar ne zaman mezun olacaklar, elimizdeki talep hangi yll neyi gerektiriyor. Aradaki boşlukları ilave eğitim yatırımlarıyla dolduracak şekilde il bazında okul, program, ögretmen, ögrenci ihtiyaçları ile bunlar için gerekli olan kaynak ihtiyacını belirliyoruz. (GYK-2)

GYK-2'ye göre eğitim planlaması sürecince üç önemli adım bulunmaktadır.

Birinci adımda; insangücü planlamasına yönelik Devlet İstatistik Enstitüsü (şimdiki TÜIKK) kanalıyla hanehalkı işgücü araştırmaları, hanehalkı gelir araştırmaları yaptırılarak işkollarında hangi işgücüne gereksinim duyulduğu saptanmaktadır.

İkinci adımda, gelecekte yatırım yapılacak iş kolları belirlenerek gereksinim duyulacak işgücünün sayısı ve alanları belirlenmektedir.

Üçüncü adımda; eldeki işgücü sayıları, gelecekte gereksinim duyulacak işgücü sayıları ve eldeki kaynak durumu dikkate alınarak, hangi alanlarda, hangi sayıda işgücünün, hangi okullardan, ne zaman mezun edileceğine ilişkin hedefler mevcut okul, mezun, öğretmen, araçgereç durumu dikkate alınarak saptanmaktadır. Burada hedefler belirlenirken planın aktörleri kendisini daha fazla zorlasın, o dönemde daha fazla kalkınma meydana gelebilsin diye genellikle olması gerekenden daha yüksek belirlendiği vurgulanmaktadır. Bu şekilde gerçekçi olmayan hedeflerin belirlenmesi, bu hedeflere ulaşılamama nedenlerinden birisi olarak karşımıza çıkmaktadır.

Eğitim planlama sürecinde PERT yardımıyla çalışmaların kimin tarafından ne zaman hazırlanacağı ve kime verileceği belirlenmektedir. Bir makro modelde girdi çıktı tablolarıyla hangi sektörün malının çıkıp hangi sektöre girdi olacağı, hangi malların nihai mal olacağı belirlenmektedir.

Kaynak tahsisine yönelik karar Yüksek Planlama Kurulu tarafindan verilmekte, verilen karara göre DPT tarafından eğitim planlamasına başlanmaktadır.

$\mathrm{Bu}$ süreçte gereksinim duyulan nüfus istatistikleri (yaş grupları, kız erkek dağılımları, il dağılımları, bölge dağılımları gibi) eski adıyla Devlet İstatistik Enstitüsü şimdiki adıyla Türkiye İstatistik Kurumu'ndan sağlanmaktadır. Bu istatistikler ile yani okullarda ne kadar öğrenci olduğu, bunların ne zaman mezun olacağı, il bazında okul, program, öğretmen, öğrenci gereksinimleri belirlenmektedir. Bundan sonraki aşamada da bunlar için gerekli olan kaynak gereksinimi belirlenmektedir.

DPT'nin kuruluş yasasında yer alan ve DPT'ye özgü bir yapı olan özel ihtisas komisyonları kalkınma planlarının en özgün öğesini oluşturmaktadır. Bu komisyonlara ilişkin görüşme yapılan kişilerin görüşlerine aşağıda yer verilmiştir;

"Plan çalışmalar başladiğında özel ihtisas komisyonlarını topluyoruz. Özel ihtisas komisyonlarına, konuyla ilgili olan kuruluşların yetkilileri katılıyor. Katılımcılar politika önerileri ve taleplerini getiriyorlar. Özel ihtisas komisyonları...yükseköğretim, ortaögretim vb. ayrı ayrı toplanır. Bunların raporları yayınlanır...bunların hepsini planlarl yaparken kullaniyoruz." (GYK-2)

"DPT/KB'nin en temel bulgularından biri olan ve katılımcllı̆̆ sağlayan özel ihtisas komisyonlarımı var... Bu komisyonlara sektörle ilgili olan herkes katıllyor. Her katılımcının farklı bakış açısı var. Bu katılımcılar sorunlara bir çözüm önerisi getiriyor. Bizler bu çözüm önerilerinden hareket ederek politikalar oluşturuyoruz." (GYK-10)

"Özel ihtisas komisyonları demokratik ortamdır. Bu demokratik ortama herkes kendi görüşlerini, taleplerini, politika tekliflerini getirir, birbirleri ile tartışılar... Buraları biz politika belirlemek, toplumun nabzını tutmak, katılımı sağlamak için kullanırız. 
Fakat katılımcıların getirdikleri talepler Türkiye bütçesinin şöyle bir elli misli filan olur. Bunları daraltmak zorundasin..." (GYK-2)

"Kalkınma planları hazırlanırken bizdeki en temel nokta özel ihtisas komisyonlarıdır. Özel ihtisas komisyonları vasitastyla biz tüm sorunlara hâkim olabiliyoruz.” (GYK-3)

"Özel ihtisas komisyonlarına tüm toplum katmanlarından insanlar çağriliyor. Özel ihtisas komisyonlarına üyeleri belirlerken bizim etkimiz oluyordu. İs yapabilecek insanlarl, değişik görüşler yansitabilecek kişileri davet ediyorduk... Dengeliyorduk. Bazı konularda da bazen görüş çıkmaz. Kararın da çıkması için düzenlemeler yapıyorduk. Bunu Milli Eğitim Şûraları'nda yaparlar. Milli Eğitim Şûraları'na da toplumun tüm katmanlarından adam çağırılır. Milli Ĕgitim Bakanlığı'nın önem verdiğ $i$ konunun çıkması için oylamada ăgırlı̆g kazanabilmek için bakanlık ve il teşkilatlarından fazla sayıda adam getiriliyor. Sonuçta oylama yapıliyor kabul edilmezse, bakan zor duruma düsser..." (GYK-3)

GYK-2, GYK-3 ve GYK-10 tarafindan belirtilen görüsslere göre;

Kalkınma planlarının hazırlanması sırasında tüm sektörler için oluşturulan özel ihtisas komisyonları eğitim planlaması çalışmalarında da oluşturulmaktadır. Ortaöğretim, yükseköğretim vb. alanlar için ayrı ayrı özel ihtisas komisyonları kurulmaktadır. Bu komisyonlara eğitim ile ilgili kuruluşların temsilcileri çağırılmaktadır. Komisyonlara farklı görüşten temsilciler davet edilmektedir.

Özel ihtisas komisyonlarında katılımcılar politika önerilerini komisyona getirmektedir. $\mathrm{Bu}$ öneriler politika belirlemek, toplumun nabzını tutmak, katılımcı plan oluşturmak amacıyla kullanılmaktadır. Özel ihtisas komisyonlarının işleyişinde konular demokratik ortamda katılımcılar tarafından tartışılmakta, kararlar oy çokluğuyla alınmaktadır. Komisyon çalışmaları rapor olarak yayınlanmaktadır. DP/KB'nin bu raporları plana olduğu gibi yansıtmak zorunluluğu bulunmamakta ancak bu raporlardan yararlanılmaktadır. Komisyonda sorunlara ilişkin çok yönlü tartışmalar yapıldığı için uzmanların konu hakkında çok yönlü bilgi sahibi olabilmektedir. Özel ihtisas komisyonlarında planlama uzmanları koordinatör ve gözlemci olarak görev yapmakta, oy hakları bulunmamaktadır.

Komisyon üyelerinin konularına ilişkin genel olarak çok hazırlıklı olmadıkları, bütçe olanaklarını dikkate almadan çok fazla taleple geldikleri görüşülen kişiler tarafindan özellikle vurgulanmaktadir.

Eğitim planlamasında görev alan kişilerin çalışma ortamına ilişkin GYK-3 ve GYK-8 tarafindan belirtilen görüşler ise şöyledir:

"Sosyal planlamada bir grup halinde çallşlyorduk, herkes görüşünü söylüyordu. (GYK-8) Planı tamamen uzmanlar yazar, daire başkanı uzmanlarla toplantılar yapar onları nihai hale getirir, genel müdürün katıldiğı toplantılarda yeniden değerlendirilir, müsteşar yardımcısı katılır yeniden değerlendirilir. En son hükümete sunulmadan önce müsteşar başkanlığında günlerce toplantı yapılır tek tek sektör sektör müsteşarın katıldığı toplantıya müsteşar yardımcısı, genel müdür, daire başkanları ilgili uzmanlar katılirlar. Plana son şekli verilir. Ondan sonra da hükümete sunulur. Siyasi olabilecek hedefler konusunda hükümetin görüşünü bekleriz. (GYK-3)

Sosyal Planlama'da çalışmalar grup çalışması şeklinde yapılmakta, plana yönelik herkesin görüşünü söylediği demokratik bir ortam bulunmakta, plan uzmanlar tarafindan hazırlanmakta, hazırlanan taslak plan hiyerarşik olarak daire başkanı, genel müdür, müsteşar yardımcısı, müsteşar başkanlığında tek tek sektör sektör ayrı ayrı tartışıldıktan sonra hükümete sunulmaktadır. Alttan yukarıya doğru hiyerarşik olarak hazırlanan ve tartış1lan plan hükümetin isteklerini içerecek şekilde oluşturulmaktadır.

DPT/KB'de eğitim planlaması çalışmalarında kaç kişinin görev aldığına ilişkin görüşülen kişilerin görüşlerine baktığımızda; 
Eğitim planlaması çalışmalarının dönemlere göre değişmekle beraber ortalama sekizdokuz kişi tarafindan yapıldığı, geçmiş dönemlere göre günümüzde öğrenci sayısı, üniversite sayısının çok arttığı, DPT'nin pek çok görevini Yükseköğretim Kurulu ve Milli Eğitim Bakanlığı' na devrettiği, DPT bu görevlerini devretmeseydi eğitim planlaması için 20-25 kişinin çalışması gerekeceği GYK-6 tarafindan ifade edilmiştir.

\title{
Ĕ̆itim Planlaması Çalışmaları Sürdürü̈lürken Bir Eğitim Planlaması Yaklaşımının Temel
} Alınıp Alınmadı̆̆ına İlişkin Bulgular

İnsangücü gereksinimi yaklaşımına ilişkin görüşme yapılan kişiler tarafından aşağıdaki görüşler belirtilmiştir:

\begin{abstract}
"İnsangücü ihtiyaçlarına göre bir eüitim planlaması baştan kabul edilmiştir...1980'lerden itibaren, liberal yaklaşımların dünya ölçeğinde yeniden itibar kazanmastyla, bilahare bunun neoliberalizme dönüşmesiyle birçok sahada olduğu gibi eğitim sahasında da planlama yapma fikri zayıflamıştır. 1990’lı yillar geldiğinde özel üniversitelerin açılması, bunların sayısının gittikçe artması bir insangücü planlamasına imkân vermedi. Dolayısıyla insangücü ihtiyaçlarına göre bir eğitim planlaması bilhassa yükseköğretimi kastederek söylüyorum yıllar içinde çok kan kaybetmiş bir yaklaşımdır..." (GYK-1)

“Çoğunlukla DPT insangücü planlaması kullanır..." (GYK-2)

"Beşinci Plan'a kadar insangücü ihtiyacı kullanıldl...Insangücü planlamasında mota mot hesaplayamıyorsunuz. Sağllk ve eğitimde hesabr yapıyorduk öbür tarafi talebe birakiyorduk..." (GYK-3)

“Biz insangücü planlaması odaklıyız DPT'de. Eğitim planlaması çalışmalarında, makro hedefler içinde insangücü planlaması boyutlarında değerlendirmeler yaptı.... Insangücü planlart sağllk, ĕgitim ve teknik hizmetler olmak üzere üç sektörde yapıliyordu...Başka sektörlerde, mesleklerde yapılmıyor muydu? diye bir soru aklınıza gelebilir...mesleklerdeki mobilite nedeniyle bir kimyacının bir pazarlama eleman olabildiği bir dünyada bu tür tahminleri yapmak zorlaşlyor. Zaten gelişmiş ülkelerde de insangücü tahminleri bu üç temel alanda gerçekleşiyor." (GYK-8)

“...Bizim zamanımızda insangücü planlamasından hareket ederek eğitim planlaması yapıliyordu. Özellikle yüksekögrretim, mesleki eğitim için geçerli bu.” (GYK-10)

"...Insangücü planlaması yöntemlerine biz lise düzeyinde başvururduk. Çünkü orada genel lise, mesleki lise ayrımı vardl. Biz mesleki lisenin lehine olması gereken unsurları dikkate alırdık ama bu konuda Türkiye de, DPT de projeksiyonlarına hiç uyamad,, tahminlerini yerine getiremedi... Insangücü gereksinimlerinin katı olarak dikkate alındiğı okullar yüksekögretimdir..." (GYK-6)
\end{abstract}

Görüşme yapılan kişilerin çoğunluğunun görüşlerine göre;

DPT'de, insangücü gereksinimi modeli uygulanırken öncelikle sektörlerin yatırım gereksinimi dikkate alınarak gereksinim duyulan insangücü belirlenmektedir. Bu insangücü gereksiniminin karşılanması için üniversite bölümleri ve kontenjanları belirlenmektedir. İnsangücü gereksinimi yöntemine ortaöğretim ve yükseköğretimde başvurulduğu görülmektedir. İnsangücü gereksinimi modelinde insangücü gereksiniminin tam olarak öngörülememesi gibi bir engel söz konusu olabilmektedir. İnsangücü gereksinimi yönteminin yükseköğretimin devlet tekelinde olduğu ülkelerde daha kolaylıkla uygulanabilirken serbest piyasa sisteminin hâkim olduğu, özel üniversitelerin çoğunlukta olduğu ülkelerde bu modeli uygulamanın oldukça güç olduğu görülmektedir. Son zamanlarda ülkemizde özel üniversite sayısının hızla artmasıyla insangücü gereksinimi yöntemini kullanmak neredeyse imkânsız hale gelmiştir. 1980'lerden itibaren neoliberalizmin hız kazanmasıyla insangücü gereksinimi yönteminin güç kaybettiği görülmektedir. İlk dört plan döneminde üniversite sayısının az olması nedeniyle insangücü gereksinimi yöntemini uygulamanın daha kolay olduğu söylenebilir. Kalkınma planları ve görüşme yapılan kişilerin belirttikleri doğrultusunda DPT'de Beşinci Beş 
Yıllık Kalkınma Planı'na kadar eğitim planlamasında insangücü gereksinimi yönteminin kullanıldığı görülmektedir.

Beşinci Beş Yıllık Kalkınma Planı'ndan itibaren yükseköğretimde sağlık, eğitim ve teknik işgücü için insangücü gereksinimi yönteminin kullanılmaya devam edildiği diğer meslekler için toplumsal istem yönteminin kullanıldı̆̆ı görülmektedir.

Toplumsal istem yaklaşımına ilişkin görüşme yapılan kişiler tarafından aşağıdaki görüşler paylaşılmıştır:

“...okula müracaat eden çocuklar, ilk olarak ailenin istekleri ve zorlamalartyla, ikinci olarak arkadaşlarının etkisinde kaliyorlar. Mesela işletme okumak diye bir şey çıklyor herkes işletme okuyor, piyasada işletmeci bolluğu oluyor... Ĕger sosyal talebe cevap verecekseniz, bir süre sonra bunlar çıtktkları zaman iş bulamayacak bu şimdiden belli. Dolayısıla sosyal talebi yönlendirici mekanizmaların kullanılması lazım. Bu mekanizmalardan bir tanesi de meslek rehberliği..." (GYK-2)

"1960'lı yıllardan itibaren köyden kente bir göç dalgası başladı...eğitime aşırı bir talep söz konusu oluyor. Burada da sosyal talep yaklaşımı gündeme gelmiş.” (GYK-3)

"Çıraklık ve Mesleki Eğitim Kanunu çok önemli bir kanun. Almanya'y esas almışlar, dual eğitim sistemi getirelim, ögrenci üç gün okula gitsin, iki gün işyerinde pratik yapsin denilmiş. Fakat uygulamada bazı problemler ortaya çıkmış. Nedenine bakıldiğında; küçük ilçelerde elektronik, bilgisayar gibi bölümler açıyorsun ama bu bölümü tercih eden ögrenciler bu ilçelerde uygulamalı eğitim imkânı bulamıyorlar. Bu bölümleri böyle küçük yerlerde açmamakta firsat eşitliği açısından haksızlık gibi gözüküyor. Açılınca doğal olarak bir toplumsal talep yaratıyorsun...” (GYK-3)

"Insangücü planı şimdi terk edilmiş, yerine toplumsal istem yöntemi kullantliyor... Ben 10 yıl üniversite veya fakülte kuruluş yazıların hazırladim. Bu yazılarda "yükseköğretimde okullaşma oranının artırllabilmesi ve yükseköğretime olan sosyal talebin karşılanabilmesi için şu fakültenin, şu üniversitenin kurulmasina izin verilmiştir" ifadesini kullanırdım." (GYK-7)

Toplumsal isteme yöntemine yönelik görüşme yapılan kişiler tarafından aşağıdaki görüşler ifade edilmiştir:

Meslek tercihi konusundaki öğrenciyi ailesinin baskı altına aldığı ve yönlendirdiği, öğrencinin üniversitede bölüm tercih etme konusunda arkadaşının etkisinde kaldığı, bunun sonucunda da dönemlere göre belirli alanlarda talebin arttı̆̆ı görülmektedir. Özellikle 1960'lardan itibaren köyden kente göç yoğunluğu gibi nedenlerle eğitime yönelik toplumsal istemin artması dikkat çekmektedir. Bunun sonucunda toplumda bazı bölüm mezunlarının ihtiyaç fazlası olduğu, toplumsal istemin olumsuzluklarını azaltmak için yönlendirme mekanizmalarını etkin olarak kullanılması gerekmektedir. DPT' de insangücü planlaması yerine toplumsal istem yönteminin ağırlıklı olarak kullanılmaya başlandığı GYK-2, GYK-3 ve GYK-7 tarafindan ifade edilmiştir.

Maliyet/Yarar yaklaşımına ilişkin görüşme yapılan kişiler tarafından aşağıdaki görüşler ifade edilmiştir:

“... maliyet yarar analizi...böyle teşkilatıyla metodolojisiyle kullanılan bir şey değil biraz ezbere...” (GYK-4)

"Maliyet yararı da dikkate aldiğımız yerler vardl. Mesela kı liseleri maliyet yarar analizinin sonucunda yararı maliyetinden daha yüksek gözükmüyordu... Kız meslek liseleri gereksiz dikiş nakış ögretmeni yetiştiriyor gibi düşünülürdü. Halbuki bu okullar, kızlar arasında okullaşma düzeyini artıran bir faktördü. Bu okullar olmasaydl, veli belki de çocuğunu ortaokula, liseye göndermeyecekti. Belki de bu okul var diye gönderdi. Dolayısiyla maliyet yararın eksik tarafi buydu." (GYK-6)

"Maliyet yarar analizleri projeler üzerinden yapıliyor. Dördüncü Plan'dan sonra Meclis Plan Bütçe Komisyonu'nda milletvekilleri tarafindan "seçim bölgeme ben bir 
okul yaptırdım" demek için plan dışında okullar dâhil ediliyor. Burada maliyetleri yararlarından fazla oluyor." (GYK-2)

DPT'de maliyet yarar analizinin tüm teşkilat tarafindan metodolojisiyle uygulanan bir yöntem olmadığı, kız meslek liselerinin maliyet etkinlik analizi sonucunda yararının maliyetinden az olduğunun DPT uzmanları tarafindan değerlendirildiği ancak bu okulların velilerin kız öğrencileri okula göndermesini kolaylaştırdığının sonradan anlaşıldığı, maliyet yarar analizlerinin projeler üzerinden yapıldığı, Dördüncü Beş Yıllık Kalkınma Planı'ndan sonra TBMM Plan Bütçe Komisyonu'nda milletvekilleri tarafindan plana dâhil edilen okullar nedeniyle maliyet yarar analizlerinin bozulduğu, maliyetlerinin yararlarından fazla olduğu GYK-2, GYK-4 ve GYK-6 tarafindan ifade edilmiştir.

\section{Ĕ̈itim Planlaması Sürecinde Önceliklerin Neler Olduğuna İlişkin Bulgular}

Eğitim planlaması sürecindeki önceliklere ilişkin görüşme yapılan kişiler tarafından şu görüşler bildirilmiştir:
“...ěgitimin bütün kademeleri mühimsenirdi.” (GYK-1)
"Nitelikli eğitim her zaman hedefimiz olmuştur...Esas önceliğimiz meslek eğitimiyle teknik eğitimdir...” (GYK-2)
"Hükümet ne kadar kısıntı yaparsa yapsın eğitim öncelikli sektörler arasında yer alıyor fakat bazen 8-10 tane sektör öncelikli gösteriliyor. Hiçbirine gerçekten öncelik veremiyorsun ... Genelde mesleki eğitim önceliklidir.” (GYK-3)
"Öncelikler bilgi toplumuna ayak uydurmak için nüfusun genel eğitim düzeyinin artırllmasıdır... Türkiye'de artık okula gitmeyen insanları ilköğretime kazandırmayla değil niteliği artırmaya yönelik bir endişe yavaş yavaş kendini göstermeye başladı." $(G Y K-4)$
“...Okulların fiziki yapılaşmasını, yarım yatırımın tamamlanmasını, okul öncesi eğitimi, mesleki ě̆itimi önceliğe aldık...” (GYK-5)
"Nitelik hep söylenmiştir ama saytyı çoğaltmak, okullaşmak ön planda tutulmuştur." (GYK-7)
“...öncelik olarak zorunlu eğitim dikkate alınıyordu.” (GYK-10)
“...eğitimde kalite de gündeme geliyordu.” (GYK-10)

Eğitim kademeleri arasında bir önceliklendirme olmadığı sadece bir görüşmeci tarafindan ifade edilmiştir.

Nitelikli eğitimin her zaman bir öncelik/hedef olduğu, meslek eğitimiyle teknik eğitimin insangücü planlamasında esas önceliği oluşturduğu, fazla sayıda sektöre öncelik verildiği için gerçek anlamda öncelik verilemediği, bilgi toplumuna ayak uydurmak ve nüfusun genel eğitim seviyesini yükseltmenin öncelik olduğu, eğitimde niceliksel olarak belirli noktalara gelindiği için nitelikli eğitimin öncelikli hale geldiği görüşülenlerin çoğu tarafından belirtilmiştir.

Şimdiye kadar hazırlanan on kalkınma planında eğitime ilişkin önceliklerin aşağıdaki gibi olduğu belirlenmiştir.

Birinci Beş Yıllık Kalkınma Planı'nda; toplumun eğitim düzeyinin yükseltilmesi ve Türk toplumunun gereksinimlerine uygun insan yetiştirilmesi, öğretmen yetiştiren kurumların geliştirilmesi, ortaöğretimde öğretmen açığının kapatılması, yükseköğretimde araştırma fonksiyonunun geliştirilmesi öncelik olarak belirlenmiştir.

Dördüncü Beş Yıllık Kalkınma Planı'nda; nitelikli insangücünün yetiştirilmesi, işgücünün sürekli olarak eğitilmesi öncelik olarak belirlenmiştir.

Beşinci Beş Yıllık Kalkınma Planı'nda; meslekî ve teknik ortaöğretime öğretmen yetiştirilmesi, Atatürk ilke ve inkılaplarının benimsetilmesi, iyi vatandaş yetiştirilmesi, Türkiye'nin menfaatlerinin farkında olan ve bunları savunan nesillerin yetiştirilmesi, öğrencilere kazandırılacak bilgi ve becerilerin hayata dönük olması, örgün eğitim sisteminden ayrılarak daha erken yaşta hayata atılma durumunda olan gençlere yaygın eğitim yoluyla meslek kazandırılması, hizmet içi eğitim programlarının kamu ve özel bütün işyerlerinde verimliliği 
artırıcı ilkeler gözetilerek yürütülmesi, orta seviyeli teknik eğitime ağırlık verilmesi, yükseköğretimdeki mevcut kapasitenin ekonominin insangücü gereksinimleri doğrultusunda kullanılması, yükseköğretime geçişte firsat eşitliği sağlanması, eğitim sisteminin her kademesinde eğitimin niteliğinin yükseltilmesi, öğretmenlerin işbaşında yetiştirilmesine dönük programlara ağırlık verilmesi, eğitimde fiziki alt yapının rasyonel bir şekilde kullanılması, eğitim sisteminde döner sermayenin düzenlenmesi öncelik olarak belirlenmiştir.

Altıncı Beş Yıllık Kalkınma Planı'nda; şehirleşme hızının yüksek olduğu yerlere eğitim yatırımlarına öncelik verilmesi, parasız yatılılık ve burs verme sisteminin yeniden düzenlenmesi, mesleki teknik eğitime öncelik verilmesi, yaygın eğitimde istihdama yönelik beceri eğitimi verilmesi, öğretmenlik, sağlık bilimleri, enformatik, elektrik-elektronik, bilgisayar, endüstri mühendisliği, yabancı diller, yönetim bilimleri, işletmecilik, uluslararası ilişkiler dallarında daha fazla mezun verilmesi, ara kademede elektronik, bilgisayar, turizm, hemşirelik, sağlık teknisyenliği alanlarında daha fazla mezun verilmesi öncelik olarak belirlenmiștir.

Yedinci Beş Yıllık Kalkınma Planı'nda; eğitimin sektörler arasında öncelikli olması öncelik olarak belirlenmiştir.

Sekizinci Beş Yıllık Kalkınma Planı'nda; eğitime ayrılan kaynakların artırılması, müfredat programlarının güncelleştirilmesi, eğitim altyapı yatırımları, mesleki ve teknik eğitim öncelik olarak belirlenmiştir.

Dokuzuncu Kalkınma Planı'nda; öncelikli sektörler arasında yer alan eğitimin kamu yatırım payının artırılması, trafik eğitimi, özel eğitim, okulların bilgi ve iletişim teknolojileri altyapısının geliştirilmesi öncelik olarak belirlenmiştir.

İkinci ve Üçüncü Beş Yıllık Kalkınma Planı ile Onuncu Kalkınma Planı’nda eğitime ilişkin bir önceliklendirme yapılmamıştır.

\section{Ĕ̈itim Planlamast Sürecinde Hedeflerin Nasıl Belirlendiğ̈ine İlişkin Bulgular}

Eğitim planlaması sürecinde hedeflerin nasıl belirlendiğine ilişkin görüşme yapılan kişiler şunları belirtmişlerdir:

“...gelişmiş ülkelerin standardı denilen bir kriteri önünüze koyarsınız... Imkanlar, kaynaklar ve ihtiyaçlar arasında bir denge kurulmaya çalışılır.” (GYK-1)

"Piyasadan gelen insangücü hedefleri veriliyor. Ona göre de eğitim planlamasl; eğitimin hedefleri, insangücü hedeflerinin bölünmesi suretiyle yapılyyor." (GYK-2)

“...dünyadaki gelişmeleri analiz ediyoruz ... hedeflerimizi belirliyoruz.” (GYK-4)

"Hangi alanda ne yapmayı planlıyorsak, o alandaki mevcut verilerin ışığında ihtiyaç durumumuza bakıyoruz. Nüfus artışımıza, ögrenci artışımıza, iç göçümüze bakıyoruz." $(G Y K-5)$

“...OECD, BM, UNESCO'nun yayınlarından dünyada eğitimin gidişatına dair verileri takip ederdik...uluslararası konferanslara katılma konusunda da şansliydık...Bunların yanında özel ihtisas komisyonları ve kurumlardan gelen taleplerin önemli bir payı vardir...̈̈ncelikleri yine planlama uzmanı belirliyordu ama hükümetten gelen talimatlar vardir..." (GYK-6)

“...mevcut alt yapıyı dikkate alıyoruz. Afaki bir hedef belirlemiyoruz...gelişmiş ülkelerin standard nedir? Buna bakıyorsunuz." (GYK-7).

"Hükümet programı bu hedeflerin tespit edilmesinde bağlayıcı bir unsur olarak göz önünde bulundurulur. Eğer burada yapılan teknik bir çalışma hükümet programında olan hedefler ile çatışıyor ise hükümet programdaki hedefler baz alınır." (GYK-9)

"Yasalardaki hedefler öncelikle o dikkate alıniyordu... Planlamalarda kaynağa da baklliyordu." (GYK-10)

Görüşme yapılan kişilerin çoğunun görüşüne göre eğitime yönelik hedeflerin belirlenmesinde: Gelişmiş ülke standartları dikkate alınmaktadır. OECD, BM, UNESCO gibi uluslararası kuruluşların yayınları uzmanlar tarafından sıkı bir şekilde izlenmektedir. Eğitim ile 
ilgili uluslararası konferanslara katılım sağlanarak dünyadaki eğilimler ve gelişmeler yakından takip edilmektedir. Piyasanın gereksinim duyduğu insangücü sayısı ve niteliği dikkate alınarak eğitim gereksinimleri ile kaynaklar arasında bir denge kurulmaya çalışılmaktadır. Özel ihtisas komisyonlarında alınan kararlardan yararlanılmaktadır. Hükümetten gelen talimatların etkili olduğu, yasalardaki hedeflere öncelik verildiği belirtilmektedir.

\section{Plan Hedeflerine Ulaşılıp Ulaşılmadı̆̆ının Nasıl İzlendiğine İliş̧kin Bulgular}

Plan hedeflerine ulaşılıp ulaşılmadığının nasıl izlendiğine ilişkin görüşme yapılan kişiler tarafindan aşağıdaki görüşler ifade edilmiştir:

“...okullaşma oranında neyi hedef allyorduk, ne kadar gerçekleştirdik. Bunlar hem yıllık programlarda ama bilhassa beş yıllık kalkınma planı çalışmalarında yer alırdı..." (GYK-1)

“...saylsal olarak izliyoruz... Getirilen politikaların uygulamaya konulup konulmadığıyla izliyoruz... Sonuçları izliyoruz. Mezunların istihdam durumlarını takip ediyoruz." (GYK-2)

"91 sayılı Kanun'da DPT ü̧̧ bölümdü; İktisadi Planlama Başkanlığı, Sosyal Planlama Başkanlığı, bu iki başkanlığın tedbir ve uygulamaların izleyen Koordinasyon Başkanlığı vardır. Sonra yapılan düzenlemelerle Koordinasyon Başkanlığı kaldırıldı, İktisadi Sektörler ve Sosyal Sektörler Genel Müdürlükleri oluşturularak her birim kendi uygulamasinı takip eder hale getirildi.” (GYK-5)

“İzleme değerlendirme, Türkiye'de çok sağllkl yürüyen bir süreç değil. Niceliksel boyutu olan bir araştırmayla çalışmıyorsunuz. Temenniler düzeyinde bir politika vaaz ediyorsunuz." (GYK-4)

"Kalkinma planlarl ve yıllik programlar bir kanundur. Resmi Gazete'de yayınlanır ve kamudan bunların uygulamast istenir. Bu plan ve programlara konulan hedefler ve icra edilmesi gereken önlemlerin ilgili icra makamlarınca takibi yapılmaktadır...”(GYK-5)

“...Her plan döneminde plana konan hedefler irdelenir. Plan hedefi beş ylllık sürece yayllır... Ondan sonra ylllık programlar döneminde bakllır. Birinci yul hedefine ulaşılmış mı? İkinci yıl hedefine ulaşılmış mı? Genellikle ulaşılmaz.” (GYK-6)

“...Planlama, projelerin bittiğinden veya bittikten sonra ekonomiye vermiş olduğu katklların izlenmesinden bihaberdir. Bir proje izleme veya plandaki hedefleri izleme, bunların sonucunda Türkiye'nin kalkınmasına verdiği katma değerin neler olduğunun tespiti maalesef bugüne kadar ihmal edilmiş bir husustur...çok yakın bir tarihe kadar plan ve programlarda öngörülmüşs olan hedeflerin nasıl gerçekleştiği ve nasıl seyrettigine dair çok slhhatli bir raporlama sistemi yokken bu son Onuncu Kalkınma Planı'nda öngörülmüs eylem planı çerçevesinde yer alan politikaların nasıl sonuçlar verdiğinin ve bunların kuruluşlar tarafindan nasıl yönlendirildiği veya yürütüldüğ̈̈nün raporlanması veya takip edilmesi söz konusu olacaktır." (GYK-9)

“...İcra programlarında ve yıllık programlarda sorumlular belli oluyordu. Yapılacak iş ve eylemler belli oluyordu. Bu şekilde takip ediliyordu." (GYK-10)

Belirlenen hedeflere ulaşılıp ulaşılmadığının kalkınma planlarında ve yıllık programlarda izlendiği belirtilmektedir. Bu takibin nasıl yapıldığına baktığımızda 91 sayılı Kanun'da İktisadi Planlama Başkanlığı, Sosyal Planlama Başkanlığının tedbir ve uygulamalarını Koordinasyon Başkanlığı izlemekte iken Koordinasyon Başkanlığının kaldırılmasının ardından iktisadi ve sosyal sektörler ile ilgili kurulan genel müdürlükler kendi uygulamasını kendisi izler duruma getirilmiştir.

Kalkınma planları ve yıllık programlar TBMM kararı olduğu için bir kanun niteliği taşımaktadır. Plan ve programlara konulan hedefler ve önlemlerin ilgili icra makamlarınca izlenmesi gerekmektedir. Bu izlemeye ilişkin DPT/KB plan hükümlerini uygulamakla sorumlu devlet kuruluşlarına plan hedeflerine uyma konusunda herhangi bir uyarıda bulunmadığı görülmektedir. 
Plan çalıșmalarının genel olarak niceliksel düzeyde değil de dilek ve öneri düzeyinde olması nedeniyle plan çalışmalarını izleme ve değerlendirmenin Türkiye'de çok sağlıklı yürüyen bir süreç olmadığı düşünülmektedir. DPT/KB'nin yaptığı planlarda koyduğu hedeflere ulaşılıp ulaşılmadığını izleme konusunda sorun yaşandığı iki görüşmeci tarafından vurgulanmıştır. Ancak Onuncu Kalkınma Planı'na ilişkin yapılan düzenlemelerle izlemenin daha etkili yapılabileceği belirtilmiştir.

Plan hedeflerine ulaşılamamasının nedenlerine ilişkin görüşme yapılan kişiler tarafından aşağıdaki görüşler ifade edilmiştir:

“...kaynak yetersizliği, kaynak yetersizliğinin arkasında iktisadi yapımızın, bünyevi ve strüktürel problemleri ön plandadır... Bazen coğrafi şartlar, iklim şartlarl, fiziki şartlar işi geciktirir..." (GYK-1)

"Milli Eğitim Bakanlığı'nda bakanın ve bakanlık kadrolarının sık değişmesi, yeterli kapasitede insan kullanilmamast...planlar her zaman piyasada olandan daha ilerisinde hedefler verirler ki o dönem kendisini zorlasin ve daha fazla yatırım yapılsin daha fazla kalkınma meydana gelebilsin diye." (GYK-2)

"Hükümet zaman zaman yıl içerisinde bile politikasını değiştirebiliyor. 4+4+4 yoktu, her ile bir üniversite yoktu. Sinırlı kaynak oralara gidiyor...” (GYK-3)

"Dördüncü plandan sonra Meclis Plan Bütçe Komisyonu'nda milletvekilleri tarafindan "seçim bölgeme ben okul yaptırdım" demek için plan dışında okullar dâhil ediliyor..." (GYK-2)

"Biz hedefleri böyle söylem bazında, temenni şeklinde belirliyoruz. Dolaylsıyla somutluk düzeyi çok düşük...” (GYK-4)

"Rahmetli Recep Yazıcıoğlu, Tokat'ın dağını taşını, halkın da desteğiyle okul yaptı, sağllk ocă̆ı yaptı, ihtiyaçları karşıladı ama on sene sonra köyler boşaldı. Okullar boş kald.." (GYK-6)

"Büyümeye dair finansal yetersizlikler, tahmin yetersizlikleri bir de bizim dönemimiz için yüksek enflasyon. O yüksek enflasyon bizim plan hedeflerine ulaşmada çok büyük engeldi...bir petrol şoku yaşamış, onu üzerinden bir türlü atamıyor. Ihracat gelirlerinin çoğunluğu petrol ithalatına gidiyor. Genel olarak eğitim dışı sebepler diyebiliriz." (GYK-6)

“Milli Ë̆itim Bakanlı̆̆l'nın ve Yüksekögretim Kurulu'nun kapasite yetersizliği... Hep biz hedefi yüksek koymayı marifet sayarı, toplum olarak. Halbuki o bir temennidir..." (GYK-6)

"Maliyet unsuru vardır, hedefin yüksek belirlenmesi vardır..." (GYK-7)

"Planlarda en önem verilmesi gereken hadise öngörülen hedeflerin finansman ihtiyacını çok net bir şekilde ortaya koyabilmesidir. Bugüne kadar bunlar ihmal edilmiştir..." (GYK-9)

"Siyasi ihtiyaçların zaman içerisinde değişkenlik arz etmesidir...tek bir parti iktidarında dahi değiștirilen bakanların...bile siyaseten önceliklerinin birbirinden farklı olduğu gibi bir sonuç ortaya çıkmaktadır." (GYK-9)

Kaynak yetersizliği plan hedeflerine ulaşılamamasının en önemli nedeni olarak belirtilmektedir. Bunun yanında ekonomik kriz, deprem, sel, heyelan gibi hesapta olmayan, öngörülemeyen faktörlerin hedefe ulaşmayı engellediği dile getirilmektedir. Milli Eğitim Bakanının ve Bakanlık kadrolarının sık değişmesi Milli Eğitim Bakanlığı bacağında planın uygulanmasını ve hedefe ulaşılmasını güçleştirmektedir. Ayrıca DPT tarafından yüksek hedef belirlenmesi, hükümetin plan dönemi içinde politika değişikliğine gitmesi, önceliğin ve kaynakların plan haricinde başka alanlara kaydırılması, Plan Bütçe Komisyonunda plan dışı okulların plana dâhil edilerek planın bozulması, hedeflerin temenni şeklinde olup somutluk düzeyinin düşük olması, Milli Eğitim Bakanlığı'nın ve Yükseköğretim Kurulu personelinin nitelik ve nicelik açısından yetersiz olması, il düzeyinde alınan kararlarla göçleri dikkate 
almadan yapılan okulların daha sonradan boş kalması plan hedeflerine ulaşılamayışının nedenleri olarak görüşülenlerin çoğu tarafindan ifade edilmiştir.

\section{Görüşülen Kişilerin DPT’de Görev Aldı̆̆g Dönemdeki Eğitim Planlaması Süreci ile Bugün DPT/KB'deki Ĕ̈itim Planlaması Sürecine İlişkin Bulgular}

DPT'de eğitim planlaması çalışmalarında görev alanların geçmişteki eğitim planlaması süreci ile şimdiki eğitim planlama sürecini karşılaştırmalarına ilişsin;

"Şimdi bizim zamanımızdaki planlama süreci, sayısallaştırılmış insangücü planlaması, ona dayalı eğitim planlamast ve buna dayalı istihdam planlamast şeklinde oluyordu. 1994 yılından itibaren stratejik planlamalara geçtik. Stratejik planlamada daha çok kurumların katılımı var ve kendi stratejik plan bürolarında hazırlayıp DPT'ye getiriyorlar. DPT'de üst koordinasyonu yapuliyor." (GYK-2)

Planlamanın yaşadığı değişim eğitim planlamasında da kendini göstermektedir. İnsangücü planı, istihdam planı ve eğitim planlaması birbirine bağlı bir şekilde yapılırken 1994 yılından itibaren stratejik planlamaya geçilmesiyle her kurum kendi planını kendi hazırlar duruma gelmiştir. DPT'nin de bu stratejik planların üst koordinasyonu yapar duruma geldiği GYK-2 tarafından ifade edilmiştir.

“...Bizde çok daha özgürdü. Özel ihtisas komisyonlarında ya da toplantılarda edindiğim bilgilerin verdiği cesaretle patrona karşı direnirdiniz. Şimdi bakanlık yapısı içinde bu direnç azalmıştır diye bir tahminim var benim. " (GYK-6)

DPT'nin daha özgür olduğu, görüşleri konusunda amirine direndiği, şimdi Kalkınma Bakanlığı'nda bu direncin azaldığı GYK-6 tarafından ifade edilmiştir.

"Bizim zamanımızda 5018 sayılı Kanun'un getirmiş olduğu orta vadeli program çok yillı bütçeleme, çok yill programlama yoktu. Biz yıllık planlama ve programlama çerçevesinde hareket ederdik." (GYK-9)

Eskiden y1llık planlama ve programlama çerçevesinde hareket edildiği, 5018 sayılı Kanun ile orta vadeli program, çok y1llı bütçeleme, çok y1llı programlama sürecine geçildiği, eski ile şimdi arasındaki en büyük ayrışmanın bu olduğu GYK-9 tarafindan ifade edilmiştir.

Eğitim planlaması sürecinde geçmiş dönem ile şimdiki dönem arasında herhangi bir fark olmadığı, sürecin aynı olduğu GYK-10 tarafından ifade edilmiştir.

\section{Tartışma / Sonuç ve Öneriler}

\section{Ĕğitim Planlamasında Görev Alan Personelin Aldığı Ĕ̌itime İlişkin Sonuçlar}

DPT/KB'de eğitim planlaması çalışmaları esas olarak uzman statüsündeki personel tarafından yürütülmektedir. $\mathrm{Bu}$ uzman personelin eğitim alanında lisans mezunu olma zorunluluğu bulunmamaktadır. Eğitim planlaması çalışmalarında görev alan ve bu araştırma kapsamında görüşme yapılan personelin DPT/KB'de müsteşar yardımcısı, müsteşar danışmanı, genel müdür, şube müdürü, daire başkanı, uzman, uzman yardımcısı olarak görev yaptığı belirlenmiştir. Bu personelin eğitim planlaması çalışmalarında görev alma süresinin en az 4.5 en çok 30 yıl olmak üzere ortalama 14 yıl olduğu belirlenmiştir.

$\mathrm{DPT} / \mathrm{KB}$ 'de eğitim planlaması çalışması yapanlara yönelik eğitim, eğitim planlaması konularında sistematik bir eğitim etkinliği bulunmamaktadır. Eğitim planlaması çalışmalarında görev alacak uzmanlar, uzman yardımcılığı döneminde göreve ilk başladıklarında bütün sektörlerde çalışacak diğer uzman yardımcıları gibi ortalama iki ay süreyle hizmet içi eğitim almaktadırlar. Bu hizmet içi eğitimde; Türkiye'nin önemli kuruluşları, önemli projeleri 
konusunda bilgiler verilmekte, yerinde incelemeler yapılmakta, DPT/KB'nin işleyiş̧i anlatılmaktadir.

DPT/KB'de plan çalışmalarında görev alanların yetişmesinde usta-çırak ilişkisi en önemli etkendir. Uzman yardımcısı, deneyimli bir uzmanla beraber çalışarak usta-çırak ilişkisiyle işleri öğrenmektedir.

DPT/KB'de göreve başlayan uzman yardımcısının, çalıştığı alanla ilgili tez hazırlama zorunluluğu bulunmaktadır. S1kı bir şekilde izlenen tez hazırlama etkinliği, uzman yardımcısının yetişmesinde önemli bir etken olarak görülmektedir. Tezini başarıyla tamamlayan uzman yardımcısı, uzman olmaktadır.

Uzman yardımcılarının yurt içinde ve yurt dışında yüksek lisans eğitimi almaları için olanak sağlanmakta, yabancı dil düzeyi yetersiz olanlar, olanaklar ölçüsünde yurt dışına yabancı dil eğitimine gönderilmektedir. Uzman yardımcısı ya da uzman isterse ve bütçe olanakları doğrultusunda eğitim planlamasına yönelik yurt dışında eğitimlere gönderilebilmektedir. Uzman/uzman yardımcılarının eğitim ile ilgili seminer, konferans, toplantı gibi etkinliklere katılımlarına önem verilmektedir.

DPT'nin sahip olduğu iklim ile personelinin bireysel ve mesleki gelişimine katk1 sağladığı, bu yönüyle personel tarafından DPT’nin bir okul gibi algılandığı belirlenmiştir.

Uzman yardımcılarının bütçe olanakları doğrultusunda yurt dışına yüksek lisans, yurt içinde de yüksek lisans ve doktora eğitimine gönderilmesi uzman yardımcısının kendini mesleki ve bireysel yönden geliştirmesine katkı sağlamaktadır. $\mathrm{Bu}$ olanakların DPT'nin kuruluş yıllarında sadece DPT'ye ve DPT'nin dışındaki birkaç kamu kuruluşuna sağlanmasının yüksek nitelikli personelin DPT'yi tercih etmesinde etkili olurken son zamanlarda bu olanakların neredeyse tüm kamu kuruluşlarına sağlanmasının nitelikli personelin DPT'yi tercihini olumsuz etkilediği görülmektedir.

Uzman yardımcıları göreve başladıktan üç yıl sonra bir uzmanlık tezi hazırlamaktadırlar. $\mathrm{Bu}$ tez süreci DPT/KB tarafından çok ciddi bir şekilde ele alınmakta, kurumsal olarak tez hazırlanmasına büyük önem önem verilmektedir.

Uzmanların yurt içinde ve yurt dışında seminer, konferans, kongre gibi bilimsel etkinliklere katılımı özellikle teşvik edilmektedir. Bu tür etkinliklere personelin katılımı olumlu karşılanmakta, personelin kendini geliştirmesini sağlayan bir etken olarak görülmektedir.

\section{Ĕ̈itim Planları Yapılırken İzlenen Sürece İliş̧kin Sonuçlar}

Plan hazırlıklarına planın yürürlüğe girmesinden bir buçuk yıl önce yayınlanan Başbakanlık Genelgesinin ardından başlanmakta, ortalama bir yıllık bir süreçte de hazırlanmaktadır. DPT/KB' de eğitim planlaması çalışmaları ortalama sekiz-dokuz kişi ile yürütülmektedir. Eğitim planı hazırlama sürecinde tüm sektörler için geçerli olan süreç izlenmektedir.

Kalkınma planı içinde yer alan ve kalkınma planının parçalarını oluşturan sektör planları bağımsız bir plan olarak hazırlanmamaktadır. Kalkınma planındaki bütün parçalar birbirleriyle ilişkili olduğu için DPT/KB' de kalkınma planı bir bütün olarak görülmektedir. Dolayısıyla eğitim planlaması da kalkınma planı içinde ayrı, bağımsız bir parça olarak değil kalkınma planının bütünleyicisi olarak görülmektedir.

Kalkınma planında belirtilen büyüme hedefine ulaşabilmek için sektör bazında büyüme hedefleri belirlenmektedir. Kalkınma planı ile ilgili büyük ölçekli (makro) hedefler ve politikalar daire başkanı ve daha üst düzeydeki yöneticiler tarafından belirlenmektedir. $\mathrm{Bu}$ hedefleri gerçekleştirebilmek için gereksinim duyulan insangücünü yetiştirmek amacıyla eğitim planlamas1 yapılmaktadır.

Eğitim planlaması yapılırken hedefler ve mevcut durum göz önünde bulundurularak genel politika saptaması ve kaynak dağılımı yapılmaktadır. Kaynak dağılımında yatırım ödeneğini DPT/KB planlamaktadır.

DPT/KB eğitim planlamasına makro ölçekte bakmakta, eğitim programları üzerinde durulmamaktadır. İl, ilçe düzeyindeki planlama çalışmaları Milli Eğitim Bakanlığı tarafından yapılmaktadır. 
Eğitim planlamasının üç önemli adımı bulunmaktadır. Birinci adımda; insangücü planlamasına yönelik TÜiKK kanalıyla hanehalkı işgücü araştırmaları yaptırılarak işkollarında hangi işgücüne gereksinim olduğu belirlenmektedir. İkinci adımda, gelecekte yatırım yapılacak işkolları belirlenerek gereksinim duyulacak işgücünün sayısı ve alanları ortaya çıkarılmaktadır. Üçüncü adımda; eldeki işgücü sayıları, gelecekte gereksinim duyulacak işgücü sayıları ve eldeki kaynak durumu dikkate alınarak, hangi alanlarda, hangi sayıda işgücünün, hangi okullardan, ne zaman mezun edileceğine ilişkin hedefler belirlenmektedir. Hedefler belirlenirken gerekenden daha yüksek hedefler belirlenmektedir.

Eğitim planlaması sürecinde bir karar verme ve çalışma modeli olarak kullanılan PERT şeması kullanılmaktadır. Çalışmaların kimin tarafından ne zaman hazırlanacağı ve sonuçlarının kime ya da hangi birime verileceği belirlenmektedir. Ayrıca, bir makro modelde girdi çıktı tabloları kullanılarak hangi sektörün malının çıkıp hangi sektöre girdi olacağı, hangi malların nihai mal olacağı ortaya konulmaktadır. vermektedir.

Kaynak dağıtımlarına ilişkin oluşturulan seçeneklere Yüksek Planlama Kurulu karar

Eğitim planlaması çalışmalarına başlandığında; gereksinim duyulan nüfus istatistikleri (yıllara göre yaş dağılımları, kız-erkek yaş dağılımları, il-ilçe yaş dağılımları vb.) ve eğitim istatistikleri (öğrenci, bina, derslik, öğretmen, yönetici vb.) TÜİK'ten alınmaktadır. Bu istatistikler ve hedefler dikkate alınarak kaynak gereksinimi belirlenmektedir. Görüşme yapılan kişiler tarafindan TÜİK verilerinin doğru ve güvenilir olduğu özellikle vurgulanmıştır.

Eğitim planlaması çalışmalarında katılımcılı̆̆ sağlamak, eğitim sorunlarını ve çözüm önerilerini eğitim ile ilgili kurum temsilcilerinden dinlemek amacıyla özel ihtisas komisyonları oluşturulmaktadır. Bu komisyonlara eğitim ile ilgili tüm kurum ve kuruluşların temsilcileri katılım sağlamaktadır. Özel ihtisas komisyonları oluşturulurken farklı görüşlerin olmasına, komisyondan karar çıkmasını sağlayacak üyelerden oluşturulmasında DPT/KB'nin belirleyiciliği bulunmaktadır. Burada belirli bir görüşün oluşmasına yönelik üye belirlenmesi planlamanın gerçekçi bir şekilde yapılmasına gölge düşürmektedir. İlköğretim, ortaöğretim, yükseköğretim vb. ayrı ayrı alanlarda özel ihtisas komisyonları toplanmakta, katılımcılar tarafindan sorunlar, politika önerileri komisyona getirilmekte, konular katılımcilar tarafindan demokratik ortamda tartışılmakta, kararlar oy çokluğuyla alınmaktadır. Komisyonlar, çalışmalarını rapor olarak yayımlamaktadır. DPT/KB'nin bu raporları plana olduğu gibi yansıtmak gibi bir zorunluluğu bulunmamaktadır. Plan çalışmalarında bu raporlardan yararlanılmaktadır. Planlama uzmanları bu komisyonlarda koordinatör ve gözlemci olarak görev almakta, oy hakları bulunmamaktadır. DPT/KB tarafından katılımcı plancılık anlayışı doğrultusunda geliştirilen "özel ihtisas komisyonu" uygulaması özgün ve kurumsallaşmış bir uygulama olarak görülmektedir.

Plan, uzmanlar tarafindan hazırlandıktan sonra daire başkanı, genel müdür, müsteşar yardımcısı, müsteşar başkanlığında tek tek sektör sektör tartışılmakta, ardından hükümete sunulmaktadir.

İnsangücü planı, istihdam planı ve eğitim planlaması birbirine bağlı bir şekilde yapılırken 1994 yılından itibaren stratejik planlamaya geçilmiş ve her kurum kendi planını kendi hazırlar duruma gelmiştir.

DPT'de uzmanların, görüşlerinde amirine direnebildiği, Kalkınma Bakanlığı'nda bu direncin azaldı $\breve{ı}$ belirtilmektedir.

\section{Ĕ̈itim Planlaması Yapılırken Temel Alınan Model Konusunda Ulaşılan Sonuçlar}

Görüşme yapılan kişilerin görüşlerine göre; DPT/KB'nin yaptığı eğitim planlaması çalışmalarında "İnsangücü Gereksinimi”, "Toplumsal İstem" ve "Maliyet/Yarar" modellerinin dikkate alındığı belirtilmektedir. DPT'nin kurulduğu dönemden günümüze kadar "İnsangücü Gereksinimi” modelinden "Toplumsal İstem” modeline doğru ağırlığın değiştiği görülmektedir.

"İnsangücü Gereksinimi” modeline ağırlıklı olarak ortaöğretim ve yükseköğretimde başvurulduğu görülmektedir. İnsangücü gereksinimi belirlenirken ilk önce sektörlerin (DPT'de tarım, madencilik, imalat sanayi, enerji, ulaştırma, hizmetler, konut, eğitim, sağlık, turizm ana 
sektör olarak kabul edilmiştir) yatırım gereksinimleri belirlenmekte, bu yatırımlar için gerekli olan insangücü belirlenmektedir. İkinci aşamada bu belirlenen insangücünün yetiştirilmesine yönelik eldeki kaynak ve olanaklar dikkate alınarak üniversite bölümleri ve kontenjanlar hesaplanmaktadır.

İlk dört Beş Yıllık Kalkınma Planı döneminde üniversite sayısının az olması nedeniyle insangücü gereksinimi yöntemini uygulamanın daha sonraki dönemlere göre daha kolay olduğu belirtilmektedir. Eğitim ile istihdam arasındaki dengenin kurulamaması ve mesleki hareketliliğin yüksek olması, bütün meslekler için insangücü gereksinimlerinin tam olarak hesaplanamamasına neden olmaktadır. Bu nedenle Beşinci Beş Yıllık Kalkınma Planı'ndan itibaren yükseköğretimde sağlık, eğitim ve teknik işgücü için "İnsangücü Gereksinimi" modelinin uygulanmasına devam edilmiş, diğer alanlar için "Toplumsal İstem" modeli kullanılmıştır. Kalkınma planları incelendiğinde Birinci, İkinci, Üçüncü, Dördüncü, Beşinci, Altıncı ve Sekizinci Beş Yıllık Kalkınma Planlarında teknik alanda, sağlık alanında, eğitim alanında yetiştirilmesi gereken insangücü gereksinimleri sayısal olarak belirtilmiş, Yedinci Beş Yıllık Kalkınma Planı ile Dokuzuncu ve Onuncu Kalkınma Planlarında insangücü ihtiyacına yönelik sayısal tahminde bulunulmadığı görülmüştür.

Ailenin, öğrencinin isteğini umursamadan onu, kendi isteği doğrultusunda meslek seçimine yönlendirmesi, öğrencinin üniversitede bölüm seçme konusunda arkadaşlarının etkisinde kalması (bu durum dönemlere göre farklı bölümlerde yığılmalar neden olmaktadır), köyden kente göç nedeniyle kentteki nüfusun eğitim talebinin artması, eğitim ile istihdam arasındaki dengenin kurulamaması ve mesleki hareketliliğin yüksek olması insangücü gereksinimlerinin tam olarak hesaplanamamasına neden olmuştur. $\mathrm{Bu}$ durumun eğitimde "Toplumsal İstem" modeli kullanılmasını artırdığı görülmektedir.

DPT'de "Maliyet/Yarar" modelinin projelerde dikkate alındığı ancak eğitim uygulamalarında bu yöntemin tüm teşkilat tarafindan metodolojisiyle uygulanan bir yöntem olmadığı öğrenilmiştir.

\section{Ĕ̈itim Planlaması Çalışmalarının Önceliklerinin Neler Olduğu ve Hedeflerinin Belirlenmesine İlişkin Sonuçlar}

Dünyadaki eğilimler, hükümetten gelen talimatlar, uzmanların yaptığı çalışmalar önceliklerin belirlenmesinde etkili olmaktadır. DPT/KB'de "aslolan uzman görüşüdür" anlayışının bulunmasına rağmen daire başkanı, genel müdür ve müsteşarın plana yönelik yönlendirmeleri olabilmektedir. Meslek eğitimi ile teknik eğitime, bilgi toplumu oluşturmaya, nüfusun genel eğitim düzeyini yükseltmeye ve nitelikli eğitime her zaman öncelik verildiği belirtilmektedir.

\section{Plan Hedeflerine Ulaşılıp Ulaşılmadığının İzlenmesine İlişkin Sonuçlar}

Belirlenen hedeflere ulaşılıp ulaşılmadığı kalkınma planlarında ve yıllık programlarda takip edildiği DPT/KB dokümanlarında ve görüşme yapılan kişilerden bazıları tarafindan ifade edilmesine rağmen bunun sistematik bir şekilde izlenmediği görülmektedir.

Kalkınma planlarında niceliksel hedeflerin dışında kalan hedeflerin çoğunun temenni şeklinde ve somutluk düzeyinin düşük olması nedeniyle hedeflerin izlenmesinin sağlıklı bir şekilde yapılamadığı görülmektedir.

Kalkınma planları ve yıllık programların TBMM Kararı olması nedeniyle plan ve programlara konulan hedefler ve önlemlerin ilgili kamu kuruluşları tarafindan izlenmesi zorunluluğu bulunmaktadır. Ancak DPT/KB tarafindan plan hükümlerini uygulamakla sorumlu devlet kuruluşlarına plan hedeflerine uyma konusunda herhangi bir uyarı, baskı ya da telkinde bulunulmamaktadır. Plan hedeflerini izleme konusunda etkin bir yöntem geliştirilmesine gereksinim bulunmaktadır.

\section{Eğitim Planlarının Hazırlamasında Yaşanan Güçlüklere İlişkin Sonuçlar}

Milli Eğitim Bakanlığı ile Yükseköğretim Kurulu personelinin sık değişmesi ve eğitim planlaması konusunda yeterli nicelikte ve nitelikte personelin kullanılmaması bu kurumlardaki eğitim planlaması çalışmalarının etkililiğini zayıflatmaktadır. 
DPT/KB'nin niceliksel verilere dayalı, somut hedeflere yönelik çalışma alışkanlığına sahip olmaması planın gerçekleşme düzeyinin ölçülmesinde önemli bir güçlük olarak görülmektedir.

Kalkınma planları hazırlanırken özel ihtisas komisyonu raporları dışında saha araştırmalarından yeteri kadar yararlanılmaması planın gerçekçiliği açısından önemli bir güçlük oluşturmaktadır.

Planda yazan hedef ve politikaların bir kenara bırakılarak onun dışında başka hedef, politika ve uygulamalara yönelinmesi planı hedefinden uzaklaştırmaktadır.

Kaynak yetersizliğinin hedefe ulaşamama konusunda en önemli etkenlerden biri olduğu görülmektedir. Bunun yanında ekonomik kriz, coğrafi koşullar, iklim koşulları, fiziki koşullar gibi öngörülemeyen faktörler plan hedeflerine ulaşamama sonucunu doğurabilmektedir.

DPT/KB'nin hazırladığı kalkınma planlarının ceza enstrümanının olmaması planın uygulanmasındaki uygulama güçlüklerinden biri olarak karşımıza çıkmaktadır.

Plan hedeflerinin olması gerekenden daha yüksek belirlenmesi planın uygulanması ve hedeflere ulaşılmasında önemli güçlüklerden birisini oluşturmaktadır.

\section{Öneriler}

Araştırma bulgularından yola çıkılarak eğitim planlaması uygulamalarının geliştirilmesine ilişkin aşağıdaki öneriler geliştirilmiştir.

1. Kalkınma planlarında yer alan eğitim planlarındaki hedefler niceliğe dayalı ve somut olarak belirlenebilir.

2. Belirlenen hedefe yönelik kurumların, hangi çalışmayı ne zaman tamamlayacağı belirtilebilir.

3. Plan hedefleri belirlenirken eldeki kaynağa göre belirlenebilir.

4. Katılımcılık ilkesi doğrultusunda oluşturulan özel ihtisas komisyonlarına katılan temsilcilerin belirttiği görüşler plana uygun bir şekilde yansıttlabilir.

5. Planda yer alan hedefler ve yapılacak işlemlerin daha sıkı takip edilmesine yönelik yöntemler bulunabilir.

6. Milli Eğitim Bakanlığı ve Yükseköğretim Kurulu'nda eğitim planlamasına yönelik yeterli nicelikte ve nitelikte personel çalıştırılabilir, bu personelin sık sık değişmesinin önüne geçilebilir.

7. Eğitim planlaması yapılırken üniversitelerin veya araştırma kurumlarının desteğiyle saha araştırması yapılarak, araştırma sonuçlarına göre plana yön verilebilir.

\section{Kaynaklar}

Adem, M. (1987). İnsangücü planlamas1. Ankara Üniversitesi Siyasal Bilgiler Fakültesi Dergisi, 143-160.

Adem, M. (2008). Eğitim planlaması. Ankara: Ekinoks Yayıncılık.

Börtücene, İ. (1973). Sosyal planlamanın kalkınma planı süreci içindeki yeri ve 4'üncü plan için sosyal planlama dairesi araştırma ve planlama faaliyetlerinin yürütümü ve niteliği üzerine öneriler. Ankara. Devlet Planlama Teşkilatı Dokümantasyon Servisi.

Ergun, D. (2005). Sosyoloji ve eğitim. Ankara: İmge Kitabevi Yayınları.

Gonca, N. (1983). Beş ylllık plan stratejilerinde sosyal politikalar üzerine bir değerlendirme ile sektör ölçeğinde irdeleme: nüfus politikası (Kariyer Dışı Uzmanlık Tezi). Devlet Planlama Teşkilatı, Ankara.

Güven, S. (1995). Türkiye'de sosyal planlama. Ankara: Ezgi Kitabevi Yayınları.

Hesapçığlu, M. (1984). Türkiye'de insangücü ve eğitim planlaması. Ankara: Ankara Üniversitesi Eğitim Bilimleri Fakültesi Yayınları No: 127.

Kansu, G. (2004). Planlı yıllar anılarla DPT'nin öyküsü. İstanbul: İş Kültür Yayınları.

Karakütük, K. (2012). Eğitim planlaması. Birinci Baskı. Ankara: Elhan Kitap Yayın Dağıtım.

Karayalçın, M. (1974). Kalkınma planlaması İçinde Sosyal Planlama Yaklaşım Biçimleri. Ankara: Devlet Planlama Teşkilatı.

Kurul, N. (1994). Eğitim istemi. Ankara Üniversitesi Eğitim Bilimleri Fakültesi Dergisi, 27(2). 
Ünal, L. I. ve Özsoy, S. (2010). Ĕgitim bilimleri felsefesine doğru. Ankara: Tan Kitabevi Yayınları.

Sezen, S. (1999). Devletçilikten özelleştirmeye Türkiye'de planlama. Ankara: TODAİE Yayınları. Yayın No: 293.

Tural, S. (1986). Sosyal planlama düşüncesine bağll kavramlar. Ankara: Devlet Planlama Teşkilatı.

Yıldırım, A. ve Şimşek, H. (2011). Sosyal bilimlerde nitel araştırma yöntemleri. Ankara: Seçkin Yayıncilik.

\section{Extended Abstract / Uzun Öz}

\section{Introduction}

The State Planning Organization was established in 1960 in order to realize the development by using the resources of the country efficiently in Turkey. The task of the State Planning Organization is to assist the Government and to advise on economic, social and cultural policies and objectives, in coordination of economic activities. The State Planning Organization has been transformed into the Ministry of Development through the Decree Law issued in 2011. 10 Development Plans were prepared by the State Planning Organization covering the years 19632018.

The concept of development refers to economic and social development. Economic development covers economic issues. Social development includes population policy, labor, employment, work and work issues, social security, education, health, social services, research, culture, other public services etc.

Education socializes the individual and gives them power to produce economically. Because of this production power, education plans are included in development plans.

\section{Method}

In this study, education planning practices carried out within development plans by the State Planning Organization / Ministry of Development were investigated. The research question of the current study involves; determining how the education plans are developed, identifying the problems encountered during preparation, application and monitoring phases of the education plans, and identifying the effects of the changes in planning approach to the education plans, based on opinions of the specialists, assistant specialists and the managers.

No research has been found on the opinions of experts working in the plan studies for the training plans prepared by the State Planning Organization. This research is important for did first time.

The plans prepared by the State Planning Organization directly or indirectly affect of all institutions that are of education planning. For this reason, it is important to know how these plans are prepared. In addition, it is hoped that the State Planning Organization, which has a very long-established planning culture, will enrich the field of educational planning with the knowledge and experiences of studies on training planning.

In this study, from qualitative research patterns were used in the case study design. The research question of the current study involves; determining how the education plans are developed, identifying the problems encountered during preparation, application and monitoring phases of the education plans, and identifying the effects of the changes in planning approach to the education plans, based on opinions of the specialists, assistant specialists and the managers.

The study group of the study consists of 10 people working in the State Planning Organization / Ministry of Development as an specialist assistant, specialist, department head, branch manager in the education planning studies.

The data sources used in the research can be grouped into three groups. In the first group, books, theses, papers etc. for the formation of theoretical framework. Documents, development plans in the second group, annual programs, medium-term programs, special expert commission reports, etc. Documents, and in the third group, information obtained as a 
result of interviews with personnel engaged in plan studies can be listed. The basic data source of this research is the information obtained from the interviews.

\section{Result and Discussion}

According to the results of the research;

Studies on education Planning in the State Planning Organization / Ministry of Development are carried out mainly by personnel in the expert status. These specialist personnel are not required to have a bachelor's or post-graduate degree in education. It has been determined that these personnel work for an average of 14 years in their education planning work. The studies on educational planning in the State Planning Organization / Ministry of Development are conducted with an average of eight-nine personnel.

A systematic training is not given to those who did on education planning on education planning work in the State Planning Organization / Ministry of Development. Master-apprentice relationship is the most important influence in the development of specialists.

Educational planning is not seen as a separate plan within from development plan. The education plan is seen as complementary to the development plan. While planning the training, general policies are determined and the allocation of resources is made considering the targets and current situation. Specialized commissions are set up to participate in training planning studies, to listen to training problems and suggestions for solutions from the representatives of education institutions.

It is stated in the studies of educational planning made by the State Planning Organization / Ministry of Development that the "Human Power Requirement", "Social Demand" and "Cost / Benefit" models are taken into consideration. From the day of establishment State Planning Organization to the day-to-day, it is seen that the weight from the model of "Human Power Needs" to the model of "Social Demands" changes.

Priority of the education plans are vocational training and technical training, creating an information society, raising the general education level of the population and giving quality education. Whether or not the targets identified in the plans have been achieved are monitored in development plans and annual programs.

Source inadequacy is the most important reason for not reaching the goals of the plan. The Ministry of National Education and the Council of Higher Education can employ qualified and qualified personnel for training planning and prevent frequent changes of these personnel. In the course of educational planning, field research can be conducted with the support of universities or research institutions and the plan can be guided according to the results of the research. 